\title{
DISSERTAÇÕES DE MESTRADO
}

1993 


\section{ALBA, José Maria Filippini}

Aplicação dos métodos estatisticos em prospeç̧ão geoquimica de sedimentos de corrente e rochas na região de "Isla Patrulla", distrito de "Treinta Y Tres", Uruguai. 15 de abril. 180p. Orientadora: Sonia Maria Barros de Oliveira.

Resumo: Neste trabalho foram comparados os resultados da análise estatistica dos dados de prospeç̧ôes geoquímicas regionais, baseadas em duas metodologias diferentes: amostragem de filōes de quartzo (228 amostras) e de sedimentos de corrente (341 amostras). As análises quimicas foram realizadas por espectrometria de emissão plasma para 22 elementos $(\mathrm{Fe}, \mathrm{Mn}, \mathrm{P}, \mathrm{Ag}, \mathrm{As}, \mathrm{B}, \mathrm{Ba}, \mathrm{Be}, \mathrm{Cd}$, $\mathrm{Co}, \mathrm{Cr}, \mathrm{Cu}, \mathrm{Mo}, \mathrm{Nb}, \mathrm{Ni}, \mathrm{Pb}, \mathrm{Sb}, \mathrm{Sn}, \mathrm{V}, \mathrm{W}, \mathrm{Y}$ e Zn) e por absorçăo atômica para Au (analisado só para as amostras de veios). A área de pesquisa localiza-se em terrenos pré-cambrianos, no distrito de "Treinta y Tres" (Uruguai) e possui uma extenstio aproximada de $250 \mathrm{~km}^{2}$.

O estudo estatistico correspondente a cada conjunto de amostras foi realizado separadamente, mediante a aplicaçăo de métodos uni e multivariados, na tentativa de caracterizar o comportamento geoquímico de cada população e diferenciar a resposta regional da local. De mancira acessória procurou-se avaliar a potencialidade dos métodos estatisticos em prospeç̧ão geoquímica.

A utilização combinada da análise dos componentes principais, a análise de agrupamentos e da análise discriminante permitiu definir conjuntos de amostras de feiçōes homogêneas, representando o fundo geoquimico, subpopulaçōes especificas ou as amostras marginais (outliers). As referidas subpopulaçöes foram caracterizadas pelos teores de fundo, a distribuição espacial e as associaçőes multivariadas, e relacionadas com as unidades geológicas ou seus litotipos, a ocorrência de possiveis mineralizaçôes e outros eventos de caráter regional ou local, ligados aos processos hidrotermais ou supérgenos associados.

Na parte final foram comparados os resultados de ambos os estudos, visando avaliar a informação de um ponto de vista global e procurar fontes comuns de controle do comportamento geoquímico, a nível regional ou local.

Abstract: In this work, two regional geochemical prospection surveys in Precambrian terrains ("Treinta y Tres" district, Unuguay) were compared. 228 quartz vein samples and 341 drainage sediment samples were considered. The chemical analyses were made by inductively coupled plasma spectrometry for $\mathrm{Fe}, \mathrm{Mn}, \mathrm{P}, \mathrm{Ag}, \mathrm{As}, \mathrm{B}, \mathrm{Ba}, \mathrm{Be}, \mathrm{Cd}, \mathrm{Co}, \mathrm{Cr}, \mathrm{Cu}, \mathrm{Mo}, \mathrm{Nb}, \mathrm{Ni}, \mathrm{Pb}, \mathrm{Sb}, \mathrm{Sn}, \mathrm{V}, \mathrm{W}, \mathrm{Y}$ and $\mathrm{Zn}$, and by atomic absorption spectrophotometry for Au (quartz vein samples only).

The geochemical behavior of each population sample was analysed by univariate and multivariate statistical methods. The efficiency of the statistical methods was discussed.

Principal components analysis, Clusters analysis and Discriminant analysis allowed a data set partition into relatively homogeneous domains. Each domain represented the background, specified events or outliers and they were associated to lithological, hydrothermal, environmental or mineralization phenomena.

\section{BARBIERI, Alex José}

Depósitos minerais secundários das cavernas Santana, Pérolas e Lage Branca, Municipio de Iporanga, Săo Paulo. 26 de novembro. 96p. Orientador: Raphael Hypólito.

Resumo: Neste trabalho sâo estudados os principais depósitos minerais secundários (espeleotemas) das cavernas Santana, Lage Branca e Pérolas, localizadas no Municipio de Iporanga, região sul do Estado de Săo Paulo. As cavernas desenvolvem-se em rochas carbonáticas da Formação Bairro da Serra, constituidas principalmente por metacalcários dolomiticos e magnesianos, com frequuentes intercalą̧ôes centimétricas a métricas de filitos carbonáticos. 
A percolação de águas nesses maciços rochosos produzem soluçōes ricas $\mathrm{em} \mathrm{Ca}^{2+}$, $\mathrm{Mg}^{2+}, \mathrm{SO}_{4}{ }^{2-}$ e HCO${ }^{3-}$, capazes de precipitar no interior das cavernas, minerais como calcita, aragonita, hidromagnesita, gipsita, óxidos e fosfatos. São depósitos gerados por gotejamentos, fluxo e armazenamento de soluçōes, transporte por capilaridade, exsudaçåo, que proporcionam a formaçåo de espeleotemas com hábitos cristalinos, formas e dimensões variadas. A compreensão destes mecanismos deposicionais envolveu experimentos de sintese em laboratório utilizando soluçôes saturadas de carbonato de cálcio e oxalato de amônio, além de dados químicos e mineralógicos obtidos da coleta de águas, rochas e espeleotemas. Estudou-se a gênese de estalactites, estalagmites, helictites, pérolas, leite de lua, flores, cotonetes, travertinos, dentes de cão, jangadas e crostas.

A precipitação da aragonita e hidromagnesita nas cavernas estudadas deve-se principalmente à presença de magnésio nas soluçōes mineralizantes. Na caverna Lage Branca, este elemento provém de filitos carbonáticos, enquanto no salঝ̃o Takeopa (caverna Santana), correntes de ar também influenciam a precipitaçăo de pequenas flores de aragonita. A gipsita, por sua vez, juntamente com óxido de ferro, é gerada pela oxidação de sulfetos, principalmente pirita, existente nas rochas carbonáticas. A interaçăo de guano de morcegos com rochas e espelcotemas calcíticos da caverna Santana é responsável pela formação de fostatos como hidroxilapatita e leucofosfita.

Pelos resultados analíticos das águas existentes nestas cavernas (freáticas, percolaçăo e estagnadas), nota-se que possuem diferentes indices de saturaçăo da calcita. Apresentam tanto comportamento agressivo (rio subterrâneo), como soluçoes saturadas (gotejamento das estalactites) que precipitam constantemente material carbonático.

Abstract: The study of the main secondary mineral deposits (speleothems), which oocur along the Santana, Lage Branca and Pérolas caves, is the purpose of this dissertation. The caves are located at the municipality of Iporanga, Southeast of São Paulo State.

These caves are developed mainly in dolomitic and magnesian metalimestones of the Bairro da Serra Formation, which exhibits a rhythmic interbedding of carbonatic metasiltstones and phyllites of centimetric to metric thickness.

The seepage water along this carbonate rock gets enriched in $\mathrm{Ca}, \mathrm{Mg}, \mathrm{SO}_{4}$ and $\mathrm{HCO}_{3}$ ions, enabling it to precipitate cave minerals, such as calcite, aragonite, hydromagnesite, gypsum, oxides and phosphates. These minerals are precipitated by dripping water, film flows, stagnant waters, capillary flows and exhudant water. These different discharge processes and flow velocities are responsable for the variety of speleothems with several crystal habits, forms and dimensions.

In order to understand the depositional mechanisms of these speleothems, laboratory synthesis using saturated solutions of calcium carbonate and ammonium oxalate have been undertaken, together with the analysis of chemical and mineralogical data from water samples, speleothems and rocks collected in the caves. The genesis of stalactites, stalagmites, helictites, cave pearls, moon milk, aragonite flowers (clusters), dog tooth calcite spars, calcite rafts, rimstone dams and crusts have been studied.

The precipitation of aragonite and hydromagnesite along the studied caves is mainly due to the presence of $\mathrm{Mg}$ in the seepage water. At the Lage Branca cave, the source of magnesium are the carbonatic and dolomitic phyllite intercalations between the limestone. The directed air flows is the conditioning factor for the origin of small aragonite flowers. Gypsum speleothems, together with iron oxide are generated through the oxidation of sulfides, such as pyrite, which is disseminated in some limestone layers. The interaction between bat guano and calcitic speleothems and rocks causes the formation of phosphates such as hydroxylapatite and leucophosphite.

The chemistry of the different water facies (phreatic, seepage and stagnant waters) reflected different saturation indexes of calcite. Aggressive to calcite waters, such as along the underground rivers, as well as saturated waters, as the dripping waters of stalactites, have been identified. 


\section{BARReTO, Alcina Magnólia Franca}

Estudo morfológico e sedimentológico da porção norte do mar de areia fóssil do médio rio São Franciso, Bahia. 28 de junho. 119p. Orientador: Kenitiro Suguio.

Resumo: Ao longo do médio rio São Fancisco (Bahia) encontram-se áreas de sedimentação eólica neocenozóica, constituindo mares de areia fósseis. A prinipal área de ocorrência localiza-se entre as cidades de Barra e Pilăo Arcado, e possui cerca de $5.000 \mathrm{~km}^{2}$.

O estudo morfológico da porção norte da maior concentração desses depósitos revela que o principal padrão observado consiste de grandes dunas (áraas) parabólicas compostas e complexas, associadas a formas longitudinais. Atualmente, elas estão cobertas por vegetação do tipo caatinga, c apresentam a morfologia original modificada por processos pluviais, fluviais e pedológicos. Essas modificaçōes apresentam-se com intensidades diferentes $\mathrm{e}$, associadas a outros dados, sugerem que esta sedimentação provavelmente ocorreu de maneira policiclica, com alternância de fases mais secas, com desenvolvimento de dunas, e mais úmidas, com a dissecaçăo das mesmas e formaçăo de pequenas e médias drenagens.

Através de dataçāo pelo método da termoluminescência, estabeleceu-se uma fase de desenvolvimento de dunas a cerca de 7.400 anos.

A análise de lineamentos, presentes na cobertura sedimentar eólica e no embasamento próximo, podem representar estruturas do embasamento, reativadas, afetando os sedimentos. médio de $\mathrm{N} 66^{\circ} \mathrm{W}$.

Os paleoventos eram predominantemente unimodais, com direçōes SE-NW e sentido

As areias encontram-se no intervalo granulométrico correspondente a areia fina e média e são moderadamente selecionadas. Nas dunas, a porcentagem de finos (silte + argila) varia de 0,1 a $12 \%$.

O arredondamento e a textura superficial em grãos de quartzo revelam o aumento do grau de retrabalhamento dos sedimentos de leste para oeste.

Em relação à cor das areias, uma maior disponibilidade de ferro fornecido pelos quartzitos ferriferos do Complexo de Xique-Xique e as oscilaçôes do nivel do lençol freático, mais alto junto ao rio São Francisco, dão o predominio de cores amarelas a castanhas para as amostras localizadas a leste, enquanto as localizadas a oeste apresentam o predomínio de cores brancas a cinzas.

A relação quartzo/feldspato $E$ bastante alta $(>95 \%)$, indicando supermaturidade mineralógica.

As porcentagens de minerais pesados encontradas nas areias são baixas, variando entre 0,01 e $0,5 \%$. As assembléias mostram-se relativamente pobres e constituidas principalmente de minerais do gnupo dos ultra-estáveis (zircão, turmalina e rutilo) e estáveis (cianita c estaurolita) e, mais raramente, minerais instáveis, em pequenas porcentagens (epidoto e anfibólios), localizadas apenas nas amostras mais próximas ao rio São Francisco.

Os altos indices de maturidade mineralógica (indice de ZTR) não permitiram maiores detalhes quanto determinação da área-fonte das areias, que provavelmente, trata-se de metassedimentos dos grupos Santo Onofre e Chapada Diamantina, retrabalhados pelo rio São Francisco e seus afluentes.

$\mathrm{Na}$ ausência de uma nomenclatura adequada para os sedimentos eólicos neocenozóicos do médio rio São Francisco, sugere-se a denominação de Formação Rio Icatú para os mesmos.

Abstract: Along the mid-course of the São Francisco River, Bahia state, there occur Neocenozoic eolian sediments which constitute fossil sands seas. The main occurrence, which covers $5.000 \mathrm{Km}^{2}$, is located between Barra and Pilão Arcado towns, object of this work.

The morphologic study of the northern portion of the largest concentration of such deposits shows that the main pattern consists of great composite and complex parabolic dunes (draas) associated with longitudinal forms. At present caatinga-type vegetation grows on them and their original 
morphology has been modified by pluvial, fluvial and pedologic processes. Their different intensities are registered and by interpreting sedimentological data, it is suggested that the sedimentation probably occurred polycyclically, under alternating drier and more humid environments, the former favouring the dune formation and the latter corresponding to their dissecation and development of small and medium drainages.

Through the dating method of termoluminescence a phasis of dune development has been established at approximately 7.400 years ago.

The lineaments which are present both on the basement as well as on the eolic sedimentary cover can indicate tectonic reativation.

direction.

Paleo-winds were predominantly unimodal, trending SE-NW, with average N66W

The grain size corresponds to fine and medium sand and selection is moderate. The silt+clay percentages vary between 0.1 to $12 \%$.

The roundness degrees and superficial textures of the quartz grains show as increase of reworking degree from east to west.

With regard to the colour of the sands, a greater availability of iron from ferriferous meta-quartzites of the Xique-Xique Complex and oscillation of the higher groundwater level near Săo Francisco River gave yellow to brown staining to the sands from the eastern portion, while the western ones sampled farther from Såo Francisco River exhibited white and grey colors.

supermaturity.

The quartz/feldspar ratio is very high (\$95\%) which indicates mineralogic

The heavy minerals percentages are low, varying between 0.01 and $0.5 \%$. The assemblages are relatively poor, being mainly composed by ultra-stable (zircon, tourmaline and rutile), and meta-stable (kyanite and staurolite) and more rarely, by unstable (epidote and amphiboles) minerals, the last one occurring in small frequencies and only in samples closer to the Săo Francisco River.

The high mineralogic maturity indexes (ZTR) did not allow a better discrimination of the source-areas, which may correspond to metasediments of the Santo Onofre and Chapada Diamantina Groups, reworked by São Francisco River and its affluents.

In the absence of adequated nomenclature, one may informally suggested the denomination River Icatú Formation for the neocenozoic colic sediments at the middle of the São Francisco River.

\section{CANCELIERI, Regina Aparecida Ribeiro}

Contribuição ao estudo do fluoreto nas águas subterráneas da Bacia do Médio - Tieté Regiāo de Piracicaba) - Caracterizaçăo e metodologias propostas para sua extraçăo. 13 de abril. 15lp. Orientadora: Mária Szikszay.

Resumo: A bacia do Médio Tietê engloba vários minicipios que utilizam-se de água subterrânea para seu abastecimento. Como vários poços apresentam águas com teores anormalmente altos, de fluoreto, procurou-se através deste trabalho, definir a distribuição de fluoreto nas águas dos poços localizados ao longo da Bacia.

Para tanto, desenvolveu-se um sistema de monitoramento na região onde foram feitas 216 análises especificas de água para detectar o fluoreto e 56 análises de água do tipo físico-química e bacteriológicas completas. As análises de água foram listadas e separou-se os elementos que apresentaram teores acima dos limites de potabilidade estabelecidos pela Organização Mundial de Saúde (1978) e Conselho Nacional de Meio Ambiente (1986), através de histogramas.

Através dos dados obtidos nos histogramas, que foram distribuidos num dendograma, estabeleceu-se as correlaçōes de excesso existentes entre os ions sódio e fluoreto. 
As correlą̧ōes encontradas foram devidamente evidenciadas quando encontrou-se águas bicarbonatadas sódicas na maioria dos casos, comprovando que as águas portadoras de fluoreto são pobres em cálcio.

Os teores de íon fluoreto encontrados nas águas subterrâneas variaram de 1,5 a 5,2 ppm em média (chegando a atingir $10,8 \mathrm{ppm}$ em pontos isolados), em águas que circulam através das formaçōes de Grupo Passa-Dois e do Grupo Tubarão, neste último, quando há a presença de sills de diabásio.

Como a água subterrânea destina-se ao abastecimento público, houve priorização no estudo dos métodos de tratamento para se tornar a água potável. Métodos estes que foram adequados à realidade da região.

Os métodos pesquisados foram:

a) adsorçăo com carvão de ossos - "descartado" devido à sua complexidade na operação e manutençăo, alto custo e grande quantidade de efluentes;

b) filtraçăo com resina de osmose reversa - não foi utilizado devido ao altíssimo consumo de energia;

c) adsorçăo com alumina ativada - baixo custo pois em nosso pais a alumina é barata, abundante e apresenta a "vantagem" de ocupar uma área reduzida, porém é um método demorado; e

d) simples mistura - seria o melhor dos métodos se existissem outros mananciais com água sem excesso de fluoretos.

O método que mais se adequou à regiăo foi a adsorçăo em alumina ativada que foi implantado para tratar a água subterrânea que serve como abastecimento do Municipio de Pereiras e até o "presente" momento tem apresentado bons resultados.

Abstract: The Middle Tietê basin includes several counties which use ground water for their supply. As several wells present waters with anomaly high contents of fluorine, the aims of this work are to determine the distribution of the ion along the basin.

For this reason, a monitoral system was developed in the region, where 216 fluorine analyses were made, besides 56 complete physical-chemical and bacteriological analyses. These analyses were put on a list in order to separate the samples that have fluorine content above the potability limits indicated by means of the World Organization for Health (1978), National Council of Environment and by histograms.

The obtained data were distributed on a dendogram through which it is possible to define the relationships between fluorine and sodium ions.

Those relationships became evident in the case of bicarbonated waters in almost all of the analyses, which prove that the fluorine waters have low concentration in calcium.

The fluorine ion concentration of the ground waters range from 1,5 to $5,2 \mathrm{ppm}$ in average, but could reach $10,8 \mathrm{ppm}$ in isolated points in waters which circulate through the geological formations of the "Passa-Dois" and "Tubarão" Groups, especially in the last ones when there are sills of diabase rock.

Taking in account that the ground waters are used for urban supply, it was given priority in this study to the methods of treatment in order to turn potable the waters.

The following methods were tested:

a) adsorption with bone-coal was considered not suitable for the region because of its complex operation and maintenance, high costs and great quantities of effluent production;

b) filtration through reverse osmotic resin was not used due to high power consumption;

c) adsorption with activated alumina is of low cost, since in Brazil alumina is abundant and the method requires small area. However, it is a very slow procedure; and

d) simple blending - this would be best process if there would be other sources of water without excess of fluorine. 
The best method for the region is the adsorption with activated alumina, which was established in order to treat the ground water used in the urban supply of the "Municipio de Pereiras" with good results untill to-day.

\section{CELLiGOI, André}

Recursos hidricos subterráneos da formação Serra Geral em Londrina, PR. 03 de maio. 96p. Orientador: Uriel Duarte.

Resumo: A cidade de Londrina, PR, durante os ultimos anos, tem demonstrado um grande crescimento populacional e econômico. Tal situação tem levado grande parte da população a utilizar a água subterrânea como fonte de abastecimento.

Devido às caracteristicas litológicas das rochas vulcânicas da Formação Serra Geral, sobre as quais a cidade se localiza, a circulação e armazenamento da água subterrânea ficam restritos às descontinuidades das rochas, as quais constituem as zonas aqüiferas. Tais descontinuidades compõemse de feiçōes litológico-estruturais intrinsecas de derrames vulcânicos, como diaclasamentos horizontais e verticais e estruturas vesiculares, bem como fraturamentos e/ou falhamentos de origem tectônica que afetaram essa regiâo da bacia sedimentar do Paraná.

Foi realizada uma análise cadastral, que permitiu que poços tubulares e seus dados de produção fossem plotados em um mapa, a fim de obter-se um quadro geral da disposição dos mesmos e avaliação da tendência para as vazões e capacidades especificas na área.

A distribuição de poços e seus respectivos parâmetros de produçăo indicou que diversos pontos, quando locados junto aos grandes lineamentos estruturais, possuem vazões de até $140 \mathrm{~m}^{3} / \mathrm{h}$, enquanto que a méclia por poço nessa regiâo é de $17,5 \mathrm{~m}^{3} / \mathrm{h}$. Evidenciou-se, assim, que os poços locados mediante estudos e critérios hidrogeológicos podem possuir caracteristicas de produção mais efetivas do que os demais.

Estudos hidrogeoquímicos foram também realizados, tendo por finalidade principal o conhecimento das caracteristicas fisicas e quimicas das águas subterrâneas. Os elementos maiores das águas analisadas foram plotados no diagrama de Piper, fornecendo uma tendência de águas bicarbonatadas cálcicas. Essa composiçåo evidencia uma relaçăo ampla com a natureza química dos derrames vulcanicos.

Mediante os resultaods obtidos, foi possivel o estabelecimento de áreas apropriadas para a locação de poços tubulares profundos nas rochas da Formação Serra Geral, em Londrina.

Abstract: During the last years, the town of Londrina has suffered a great populational and economic growth. Such situation has led the population to use the groundwater as source of their supply.

Londrina lies on the basaltic rocks of the Serra Geral formation. Due to the lithologic features of these rocks, the circulation and storage of the groundwater are confined to the discontinuities that are concerned to the aquifer zones. Such discontinuities are lithological and structural features of volcanic flows, such as horizontals and verticals fracturing, vesicular structures, and also fracturing or faulting as results of tectonic activities which affected this region.

A survey was carried out of yield data of tubular wells. The data were plotted in a map aiming a general view about the localization pattern and evaluation of the trend for the discharge rates and specific capacities.

The wells arrangement and their respective yield data indicated that, when drilled near of large structural lineaments, presented discharge rates up to $140 \mathrm{~m}^{3} / \mathrm{h}$, while the average in this region is $17,5 \mathrm{~m}^{3} / \mathrm{h}$. This shows that higher yield can be achieved when hidrogeological studies and planned drilling are carried out.

Hidrogeochemical studies were also done, objecting the main physical and chemical 
characteristics. The major elements plotted in the Piper diagram, showed that the waters were calcic bicarbonated. This composition shows a wide relation with the chemical nature of volcanic flows in this particular region.

This study has established favorable areas for deep tubular wells location in rocks of the Serra Geral formation in Londrina.

\section{CENTURIONE, Sérgio Luiz}

Influência das caracteristicas das matérias-primas no processo de sinterizaçäo do clinquer portland. 17 de setembro. 155p. Orientador: Yushiro Kihara.

Resumo: O estudo mineralógico do clinquer portland, bem como do material de partida para a sua fabricação contribui significativamente para a melhora da qualidade do produto final e para a reduçăo do consumo especifico, de combustível na produção.

Nesse trabalho foram analisadas doze amostras de clinquer e doze de farinha, provenientes de duas unidades produtoras de cimento, sob o ponto de vista da aptidão à clinquerizaçăo, sendo apresentadas algumas sugestǒes de alteraçōes possiveis na dosagem e na finura das matériasprimas, visando a obtenção de um produto de melhor qualidade com os custos de produção otimizados.

Foram utilizados métodos experimentais, baseados em dados microscópicos de queimabilidade de farinha em laboratório, para a previsăo do comportamento das matérias-primas frente ao processo de fabricaçăo e sua influência na qualidade do produto final.

Verificou-se que a granulometria das fases mineralógicas da farinha (sobretudo do quartzo e do calcário) e o seu quimismo são os fatores mais significativos para a fabricação do cimento portland. Os teores de grăos grosseiros de calcário $(>125 \mu \mathrm{m})$ e de quartzo $(>45 \mu \mathrm{m})$ não devem exceder, respectivamente, a $6 \%$ e $2 \%$ para que nåo seja comprometida a queimabilidade da farinha.

Métodos de previsão da resistência mecânica do cimento aos 28 dias c do grau de cominuiçăo do clínquer portland, fundamentados no conteúdo de silicatos e na dimensão dos cristais de alita, mostraram correlaçőes muito boas com os valores determinados experimentalmente.

Os resultados obtidos mostram a importância das técnicas fisico-quimicas, em particular da microscopia óptica, na previsão e acompanhamento da qualidade e consumo energético de produção do cimento portland.

Abstract: The mineralogical study of both Portland cement clinker and the raw material used for its manufacture contributes in a great extent to improve the quality of the final product and for reduce the specific energy consumption during the process.

In this work, twelve samples of clinker and twelve samples of raw mix from two cement plants were analysed regarding their burnability. Some suggestions were presented concerning possible changes in chemical composition and fineness of raw materials in order to obtain a product of better quality and optimized production costs.

Experimental methods were carried out, based on microscopic and laboratory raw mix burnability data aiming the evaluation of the behavior of the raw materials in view of the manufacturing process and its effect on the quality of the final product.

It was found that the grain size of the mineralogical phases of raw mix (mainly those of quartz and limestone) and the chemical composition there of are the most significant factors for the manufacture of Portland cement. The coarse grain contents of limestone $(>125 \mu \mathrm{m})$ and quartz $(>45 \mu$ m) should not exceed respectively $6 \%$ and $2 \%$ because it can impair the raw mix burnability.

Methods for estimating the mechanical strength of cement on the $26^{\text {th }}$ day and comminution of Portland clinker, based on the content of silicates and on the size of alite crystals showed very good correlations with the experimentally determined values. 
Results obtained showed the importance of the physical-chemical techniques, particularly of optical microscopy for control and improvement of quality and energy consumption in the Portland cement production.

\section{CITRONI, Sérgio Brandolise}

Ambientes deposicionais e significado geotectônico da sedimentaçāo do Grupo Itajai, SC. 12 de maio. 145p. Orientador: Miguel Angelo Stipp Basei.

Resumo: O Grupo Itajai, unidade estratigráfica situada na bacia do mesmo nome, localizada no vale do rio Itajai-Açu (SC), é composto por uma sucessão de sedimentos epiclásticos anquimetamórficos e por volumes subordinados de tufos, rochas vulcanicas e vulcano-clásticas de idades Eopaleozóicas.

A partir do reconhecimento de paleoambientes deposicionais e de sua sucessão, o presente trabalho identificou uma série de unidades litológicas, expressas na forma de associaçōes de fácies, conforme apresentado abaixo:

1 - Associaçöes turbiditicas

1.1 - Turbiditos densos arenosos a conglomeráticos

1.2 - Turbiditos densos gradados

1.3 - Turbiditos clássicos de média densidade

1.4 - Turbiditos diluídos

2 - Associaçōes baciais

2.1 - Hemipelagitos

3 - Associaçōes transicionais

2.2 - Depósitos de escorregamento subaquoso

3.1 - Arenitos de planícies costeiras

3.2 - Arenitos deltaicos

3.3 - Arenitos de águas rasas

4 - Associaçöes continentais

4.1 - Leques aluviais ruditicos

4.2 - Fluvial arenoso entrelaçado

Tais associaçōes de fácies foram posteriormente reagrupadas com base em critérios de campo resultando $\mathrm{cm}$ uma séric de unidades estratigráficas e de mapeamento, compativeis com sua representação na escala de 1:50.000.

Na maioria dos pontos de contato com o embasamento, a unidade basal da Bacia do Itajai é a Formação Gaspar, formada por sedimentos arenosos e areno-argilosos com estratificaçōes cruzadas de variadas escalas. Em sua porção basal ć constituida por sedimentos das associaçōes de fácies 3.1 (arenitos de planicie costeira) e 3.2 (arenitos deltaicos), agrupados sob a denominaçấo de Membro Jordão da Formação Gaspar. Para o topo, e em direção às porçőes mais centrais da bacia, esse membro grada para os sedimentos subaquosos da associação de fácies 3.3 (arenitos de águas rasas), denominada Membro Garcia da Formação Gaspar.

Em alguns pontos pelos quais se deu 0 aporte de sedimentos fluviais, a Formaçăo Gaspar é substituída pela Formaçāo Baú como unidade basal. A Formaçāo Baú também pode ocorrer na forma de intercalaçếes dentro da Formaçăo Gaspar. Apresenta a geometria de cunhas sedimentares situadas nas duas margens principais da bacia. Conglomerados constituem o Membro Ponta Aguda da Formação Baú, equivalendo à associação de fácies 4.1 (leques aluviais ruditicos). Esse membro ocupa uma posição preferencialmente basal, para o topo, ela adquire um caráter dominantemente arenoso, constituindo o Membro Blumenau, este representado pela associação de fácies 4.2 (fluvial arenoso entrelaçado).

Em direçăo ao topo, a Formação Baú é recoberta pelos membros Jordão e Garcia da Formação Gaspar e, por sobre estes, transgridem as unidades depositadas em águas mais profundas, da 
Formação Ibirama, constituída predominantemente pela associação de fácies 1.3 (turbiditos clássicos), unidade aqui denominada Membro Kroberger da Formação Ibirama. De maneira subordinada, ocorrem lentes e cunhas de turbiditos canalizados, de granulaçăo mais grossa, constituindo o Membro Ribeirăo do Bugre, formado pelas associaçẽes 1.1, 1.2 e 2.2 (turbiditos densos arenosos a conglomeráticos, turbiditos densos gradados e depósitos de escorregamento subaquoso).

Sedimentos mais finos, depositados nas posições mais distais da bacia à época da sedimentaçăo da Formaçăo Ibirama, foram separados em uma unidade estratigráfica independente, denominada neste trabalho de Formação Ribeirão do Espinho, constituída pelas associaçōes de fácies 1.4 e 2.1 (turbiditos diluídos e hemipelagitos). Ocorre de forma interdigitada no Membro Krooberger da Formação Ibirama, sendo ainda cortada por raros canais erosivos preenchidos pelo Membro Ribeirão do Bugre.

O magmatismo sin-sedimentar presente na bacia ocorre de duas maneiras: (1) como niveis restritos de tufos finos, fortemente recristalizados, situados principalmente nas formaçōes Baú e Gaspar (basais), e (2), como vulcânicas e subvulcânicas riolítico-traquiticas, com raros termos mais básicos (mugearitos), todos com tendência alçalina, que ganham importância a medida que se ascende na estratigrafia, culminando com grandes domos $\mathrm{e}$ derrames sin-sedimentares $\mathrm{em}$ meio às formaçōes Ibirama e Ribeirão do Espinho, na região de Apiúna.

A bacia sofreu a ação de deformaçôes pós-deposicionais, concentradas principalmente em seu limite sul, no qual é cavalgada pelas rochas supracrustais do Grupo Brusque. Tais deformaçóes ocorrem principalmente na forma de falhas inversas e dobras $e$ foram principalmente fruto da açăo dos cavalgamentos do Grupo Brusque que atinguiram a sua borda sul por volta de $535 \mathrm{Ma}$, tratando-se portanto de deformaçốes pós-deposicionais.

A sequência estratigráfica conforme apresentada, mostra nitidamente a ocorrência de um ciclo transgressivo, com uma sucessão continental-transacional-marinha, característica de processos de rifteamento progressivo. Essa sequência, associada à ausência de deformaçōes sin-sedimentares e ao caráter alcalino do magmatismo associado, se mostra mais compativel com o modelo de um rift continental, do que com modelos adotados por outros autores, que consideram a bacia ou como uma antefossa molássica, gerada pela carga tectônica dos cavalgamentos do Grupo Brusque, ou como uma bacia de strike-slip, produzida pela atuaçåo de falhas transpressivas.

O mecanismo que melhor explica a geração do rift do Itajai foi a açăo conjunta das tensōes produzidas pela interação entre a Microplaca Curitiba, a Microplaca Luis Alves e o Cinturão Granitóide Costeiro (ou Batólito de Paranaguá), ocorrida por volta de 560-550 Ma. A Bacia do Itajaí, portanto, seria um rift passivo, ou, utilizando-se de um termo mais adequado, um impactógeno, semelhante ao Gráben do Reno, produzido pela colisåo Europa/África.

Abstract: The Itajai Group, a stratigraphic unit located in a basin of the same name, in the ItajaiAçu River Valley (SC), is formed by a succession of eopaleozoic epiclastic anquimetamorphic sediments with subordinated volumes of tufs and volcanic and volcaniclastics rocks. This volcanism is dominantely trachytic-rhyolitic with a marked alkalic trend.

The basin has suffered its post-depositional deformations, which mainly affected its southeastern border. The deformations are mainly occurred reverse faults and folds, formed during overthrusting, of the Brusque Group which occurred at about $535 \mathrm{Ma}$.

By analysis of the depositional paleoenvironments and the stratigraphic succession, the present work has identified a group of lithological units, expressed in the form of facies association, as above follows:

1 - Turbiditic associations

1.1 - Dense arenaceous to conglomeratic urbidites

1.2 - Dense graded turbidites

1.3 - Classic medium-density turbidites 


\section{4 - Diluted turbidites}

2 - Basinal associations

2.1 - Hemipelagites

2.2 - Subaqueous slump deposits

3 - Transitional associations

\section{1 - Coastal plain sandstones}

3.2 - Deitaic sandstones

3.3 - Shallow water sandstones

4 - Continental associations

4.1 - Ruditic alluvial fans

4.2 - Braided fluvial arenaceous

These facies associations were later regrouped, using distinctive field criteria, into mapping and stratigraphic units, compatible with their representation at the 1:50.000 scale.

The most common unit in contact with the basement is the Gaspar Formation, composed of sandstones and sand-mudstones with cross stratification at various scales. In the basal portions this is formed by sediments of the facies associations 3.1 (coastal plain sandstones) and 3.2 (deltaic sandstones), grouped together in the Jordão Member of the Gaspar Formation. Towards the top, and towards the central portions of the basin, this member grades into subaqueous sediments of the facies association 3.3 (shallow water sandstones), of the Garcia Member of the Gaspar Formation.

At the main points of fluvial supply, the Gaspar Formation is replaced at the base of the sequence by the Baú Formation. This unit also can occur as intercalations in the Gaspar Formation. It occurs as sedimentary wedges at both main basin margins. The dominantly rudaceous portions constitute the Ponta Aguda Member of the Baú Formation, corresponding to the facies association 4.1 (ruditic alluvial fans). This member occupies a basal position and grades upwards to finer material represented by the sandstones of Blumenau Member representing the facies association 4.2 (fluvial sandstones).

The Garcia and Jordão Members of the Gaspar Formation cover the sandstones of the Baú Formation and are covered by the transgressive units of Ibirama Formation, predominantly formed by facies association 1.3 (classic turbidites) which includes the Kroberger and Riberão do Bugre Members. More distal turbiditic sediments, deposited at the time of Ibirama Formation sedimentation were separated as an independent unit named the Ribeirão do Espinho Formation which includes facies associations 1.4 and 2.1 (diluted turbidites and hemipelagites).

The magmatism in the Itajai Basin is mainly syn-sedimentary occurring as recrystallized fine tuffs in the lower formations (Baú and Gaspar) as well as flows and domes of alkalic rhyolitictrachytic volcanic rocks most common towards the top the Ibirama and Ribeirão do Espinho Formation.

The Itajai Basin deformation pattern is a post-sedimentary feature more strongly developed in the southeastern border where the influence of thrusting of the Brusque Group over the Itajai sediments is clear. The deformation occurs mainly as inverse faults and folds related to the thrusts from SE to NW.

A continental rift is supposed to be the origin of the Itajai Basin. This hypothesis is based on the transgressive sedimentary succession (from continental to marine environment) typical of this kind of rift; on the presence of alkalic felsic magmatism, and on the post sedimentary deformation pattern. This continental rift could be generated as a passive rift related with the Coastal Granite Belt and the Luis Alves Microplate collision in a similar context to that of Rhine Graben in Europe, formed during the Europe-Africa collision.

CLEARX, Maria Tereza de Castelo Branco Ferreira

Investigação através de modelos matemáticos em microcomputadores dos efeitos dos principais 
parâmetros hidrogeológicos $e$ dos processos atenuantes de transporte na delineação de áreas de proteção de poços (APPs) e na remediação de aquiferos contaminados. 01 de abril. 169p. Orientador: Alberto Pacheco.

Resumo: A importância da água subterrânea reside no fato de ser a água essencial à vida e, muitas vezes, ser esta a única fonte de água, ou representar uma porção significante da água total utilizada por uma cidade. A maioria dos habitantes das áreas rurais e dos subúrbios, $90 \%$ das indústrias e quase $50 \%$ dos habitantes urbanos do Brasil usam água subterrânea (Rebouças, 1988).

Nos Estados Unidos aproximadamente metade da populaçăo serve-se de água subterrânea para beber e cerca de $95 \%$ da população rural depende de água subterrânea.

A água subterrânea constitui entâo uma reserva estratégica. Ela representa $95 \%$ do volume de água doce do globo e apesar da abundância em quantidade é extremamente susceptivel à degradaçăo de sua qualidade por focos de poluiçăo. Mais grave ainda é o fato de que uma vez poluída, a descontaminaçâo do aqüiffero até um nivel de zero de concentração não pode ser obtida, ou então, a um custo financeiro muito elevado, consegue-se remediar esta poluiç̧̃o a um nível aceitável acima de zero.

O desafio, então, que enfrentam as municipalidades empenhadas no fornecimento de água de boa qualidade aos seus cidadãos é duplo: a) proteção de seus poços municipais (o ponto de suprimento mais comumente usado) para previnir que sejam contaminados $\mathrm{e}$ b) remediação dos aquiferos que, acidentalmente ou por negligencia, acabaram sofrendo contaminaçâo. Tendo em mente a importância deste assunto o governo americano estabeleceu em 1987 o Wellhead Protection Program (Programa de Proteção de Poços (PPP), inspirado em programas similares europeus, para a delineaçăo de Wellhead Protection Areas (Áreas de Proteção de Poços - APP) para todos os poços municipais.

Devido ao quase total desconhecimento do assunto pelos órgãos brasileiros, e à importância do assunto, esta dissertação de tese de mestrado aplica modelação matemática para investigar os efeitos dos principais parâmetros hidrogeológicos e processos envolvidos tanto em prevenção (APP) de contaminantes como em remediação.

Embora prevenção e remediação usem modelos matemáticos similares, estes são assuntos claramente distintos, que merecem tratamento individual. Esta tese, então, foi dividida em duas partes:

Parte I: investiga os efeitos dos principais parâmetros hidrogeológicos na fase de prevenção de contaminação de água subterrânea para poços municipais, quando as APPs são delineadas.

Parte II: investiga os efeitos de heterogeneidade geológica, parâmetros hidráulicos c processos atenuantes de transporte sobre o tempo e os esquemas de remediaçăo, quando, apesar dos PPPs, ocorre contaminação e os níveis de concentraçăo dos contaminantes precisam ser reduzidos a niveis aceitáveis para proteger a saúde pública e o meio ambiente natural.

Na parte I os efeitos dos seguintes parâmetros em APPs foram investigados, através de modelos de fluxo analíticos e numéricos:
1 - gradiente regional
2 - transmissividade
3 - anisotropia
4 - falhamento
5 - porosidade efetiva

Na parte II foram investigados, através de modelos de transporte advectivo e dispersivo, os seguintes parâmetros:

1 - dispersividade

2 - retardamento

3 - heterogeneidade

Entre os muitos resultados mostrados nesta tese pode-se citar: 
1 - Para um poço único, bombeando em aquifero homogèneo e isotrópico, e usando o Modelo Analítico de Fluxo Uniforme, a largura da APP desenvolvida é inversamente afetada pelo aumento da condutividade hidráulica, da espessura e do gradiente do aquifero onde se encontra o poço a ser protegido, e diretamente afetados pelo aumento da taxa de bombeamento deste poço.

2-O desenvolvimento da APP năo ocorre na direção perpendicular à linhas eqüipotenciais perfeitamente eqüidistantes e paralelas, se a anisotropia deste aquífero for levada $\mathrm{cm}$ consideraçāo.

3 - A condição assintótica da concentração de contaminantes $\mathrm{em}$ água subterrânea sujeita a bombeamento e tratamento mostrou estar sujeita a ter como causa heterogeneidades do aquífero, que envolve meios de baixa e alta condutividade hidráulica onde ocorre o desenvolvímento da zona que contribui água para o poço. Em poços de remediação esta condição pode representar um aumento significativo do tempo necessário de bombeamento até que uma concentração menor pré. estabelecida seja obtida.

4 - A heterogeneidade é, de todos os parâmetros investigados, aquele que causa os efeitos mais dramáticos em APPs e em esquemas de remediaçăo.

Abstract: The importance of groundwater resides in the fact that it is essential to life and, many times, it is the only source of water, or it represents a significant portion of the total water used in a city. The majority of the inhabitants living in rural and suburban areas, $90 \%$ of the industries and almost $50 \%$ of the urban inhabitants in Brazil use groundwater (Reboucas, 1988).

In the United States, approximately half of the population utilizes groundwater for drinking about $95 \%$ of the rural population depends on groundwater.

Groundwater is, then, a strategic resource. It represents $95 \%$ of the volume of the fresh water of the globe, and, despite its abundancy in quantity, it is extremely susceptible to degradation of its quality by pollution sources. Even worse is the fact that once pollution occurs, the complete cleanup of the aquifer (levels of zero concentration) likely will not be possible. Even to remediate to non-zero acceptable levels will have high financial costs (the average cleanup cost for superfund sites in the U.S. is 20 million dollars).

The challenge, then, that the municipalities face to supply good quality water to their citizens is double: a) protection of municipal wellheads (the most common supply) to prevent their being contaminated and b) remediation of the aquifers that, by accident or by negligence, end up being contaminated. With the importance of this subject in mind, the American government established in 1987 the Wellhead Protection Program (Programa de Proteção de Poços (PPP), inspired by similar European programs, for the delineation of the Wellhead Protection Area (Área de Proteça de Poços (APP)) for each municipal wellhead.

Due to the almost total lack of knowledge of this subject by Brazilian organizations, and to its critical importance, this master's thesis applies mathematical modeling to investigate the effects o: the principal hydrogeologic parameters and processes involved in prevention (APP) of contamination as well as in its remediation.

Although prevention and remediation use similar mathematical models, they are clearly distinct subjects, and they deserve individual treatment. The thesis, then, is divided into two parts:

Part I: Investigate the effects of the principal hydrogeologic parameters on the delineation of APPs (to prevent groundwater contamination).

Part II: Investigate the effects of geologic heterogeneity, hydraulic parameters and transport attenuation processes on the total time for remediation, when, despite the PPPs, contamination occurs and the concentration levels of the contaminants need to be reduced to acceptable levels to protect the public health and the natural environment.

In part I the effects of the following parameters on APPs were investigated through analytical and numerical flow models: 
1 - regional gradient

2 - transmissivity

3 - anisotropy

4 - faults

5 - effective porosity

The part II the following parameters were investigated through the use of advective and dispersive transport models:

$$
\begin{aligned}
& 1 \text { - dispersivity } \\
& 2 \text { - retardation } \\
& 3 \text { - heterogeneity }
\end{aligned}
$$

The following are some of the results found in this thesis:

1 - For a single well, pumping in a homogeneous isotropic aquifer, and using the Uniform Flow Analytical Model, the boundary limit of the developed APP is inversely proportional to the hydraulic conductivity, the thickness and the gradient of the aquifer and directly proportional to the pumping rate of the well.

2 - The development of the APP in isotropic, homogeneous, sloping aquifers produces ellipsoidal-shaped drawdown and equipotential curves. The simulation of the above situation, however, produces perfect circular drawdown curves because the available mathematical models for microcomputers do not account for the slope of the aquifer base, as suggested by Hantush (1964). If anisotropy is present, the simulated drawdown curves are ellipsoidal (like the theoretical drawdown curves).

3 - The asymptotic condition of the concentration of the contaminants in groundwater, subject to pump and treat, is shown to be able to be caused by heterogeneities of the aquifer, which involve areas of low and high hydraulic conductivity located throughout the contribution zone of the aquifer.

4 - Of all the parameters investigated, hydraulic conductivity heterogeneity is the one that causes the most dramatic effects on APPs and remediation schemes.

\section{DAVIES, Howard-Peter Kombrink}

Petrogènese e evolução crustal Pré-Cambriana da Região de Bateias (Quadricula 1:25.000 NE da folha topográfica Catas Altas 1:50.000) Quadrilátero Ferrifero - MG. 29 de setembro. 265p. Orientador: Johann Hans Daniel Schorscher.

Resumo: O mapeamento lito-estrutural, estratigráfico, de semidetalhe (esc. 1:25.000), da subquadrícula NE da folha topográfica Catas Altas 1:50.000, informalmente denominada de Quadricula Bateias, evidencia para esta região pré-cambriana a continuação dos princípios conjuntos litológicos, crustais e supracrustais que também constituem a parte leste do Quadrilátero Ferrifero, quais sejam: o complexo regional fundamental TTG arqueano constituido de rochas crustais sensu lato graniticas, sequêencias metavulcano-sedimentares supracrustais arqueanas do greenstone belt, Supergrupo Rio das Velhas, e seqüências metassedimentares proterozóicas dos supergrupos Minas e Espinhaço. Um forte condicionamento estrutural, dado por falhas de empurrăo de direçăo principal N-S com caimentos para E, caracteriza a Quadrícula em toda sua extensảo, e desenvolveu-se durante o principal evento tectonometarnórfico regional proterozóico, do Ciclo Minas/Espinhaço.

Estudos laboratoriais mineralógicos-petrográficos e litogeoquímicos complementares, evidenciaram para as rochas sensu lato graníticas do Complexo TTG, composição geral hololeucocrática, natureza poli-metamórfica-retrometamórfica pelo principal evento de metamorfismo regional proterozóico, tendência geoquímica sodi-cálcica e derivação orogênica por processos associados, metamórficos de alto grau e intrusivos-igneos. Localmente ocorrem efeitos de 
metassomatismo potássico em zonas de milonitizaçăo/cizalhamento. As seqüências vulcanosedimentares do greenstone belt Rio das Velhas incluem rochas metaultramáficas extrusivas (metakomatiitos), anfibolitos de lavas básicas, xistos máficos a metapelíticos e metassedimentos quimicos diversos. As rochas metakomatíticas evidenciam forte variabilidade geoquimica por processos anisoquimicos que afetaram grande parte dos elementos analisados, inclusive alguns dos elementos em geral considerados imóveis: Ti, Nb, Y, La, Ce, Nd, entre outros. Os anfibolitos metabásicos foram caracterizados como toleitos, variando desde olivina normativos a quartzo normativos e apresentam características de fundo oceânico, mais provavelmente de bacia retro-arco. Ocasionalmente, notam-se efeitos de processos hidrotermais-mineralizantes (pré-metamórficos) por anomalias positivas de ETRL, $\mathrm{Zr}$ e metais base, entre outros. Os metassedimentos Espinhaço, proterozóicos, representam as ocorrências mais meridionais deste Supergrupo atualmente confirmadas em Minas Gerais e incluem entre outros, conjuntos litológicos típicos das formaçêes Sopa Brumadinho e Galho do Miguel. Os metassedimentos do Supergrupo Minas, do Proterozóico Inferior, săo quantitativamente pouco expressivos na Quadrícula estudada e caracterizados por itabiritos quartzo-hematiticos com minérios ricos de hematita associada, do Grupo Itabira, Formaçāo Cauê. Seu estado de deformação e metamorfismo em comparação ao Supergrupo Espinhaço indicam origem alóctone, de nappes prémetamórficas, para o Supergrupo Minas na Quadricula Bateias. Evidências de diferenças de idade relativa elou em termos de ciclos orogênicos entre os metassedimentos dos supergrupos Espinhaço e Minas náo foram encontradas; portanto ficam incluidos num ciclo orogênico único, no Ciclo Minas/Espinhaço, considerado do Proterozóico Inferior a (?)Médio. Os metabasitos/anfibolitos da Suite Subvulcânica Básica intrudem todas as unidades pré-cambrianas da área estudada, apenas no Supergrupo Minas não foram verificadas. Estas rochas também foram afetadas pelo metamorfísmo regional do Ciclo Minas/Espinhaço. Petrologicamente, trata-se de toleitos continentais, que variam de quartzo a olivina normativos.

A Quadricula Bateias tem, em geral, caracteristicas polimetamórficas, onde se destacam a natureza "barroviana", de pressão intermediária com cianita, a polaridade com intensidade crescente de W para $\mathrm{E}$ da fácies xisto verde superior a anfibolito (?)médio, do principal evento regional, dinamotermal proterozóico do Ciclo Minas/Espinhaço. Processos geológicos posteriores incrueñ retrometamorfismo, diversos eventos de fraturamentos, soerguimentos e crosão, desde pré-cambrianos, alguns relacionados ao Ciclo Brasiliano, a fanerozóicos.

Abstract: The litho-structural, stratigraphic semi-detailed mapping of the NE sub-quadrangle of the Catas Altas (1:50.000) topographic sheet, informally called Bateias Quadrangle, has shown that this Precambrian region contains continuations of the crustal and supracrustal lithological units which constitute the castern part of the Quadrilatero Ferrifero (Iron Quadrangle), that is: the regional Archean TTG complex constituted of crustal sensu lato granitic rocks, the volcano-sedimentary Archean greenstone belt of the Rio das Velhas Supergroup, and Proterozoic metasedimentary sequences of the Minas and Espinhaço supergroups. The area has strong structural conditioning due to $\mathrm{N}-\mathrm{S}$ trending and E dipping thrust faults, developed during the main Proterozoic regional tectono-thermal event, the Minas/Espinhaco Orogeny.

Complementary mineralogical-petrographical and lithochemical studies, show that the sensu lato granitic rocks of the TTG complex have a general hololeucocratic composition. polymetamorphic-retrometamorphic nature due to the main Proterozoic regional metamorphic event, sodi-calcic geochemical tendency and orogenic derivation by associated high-grade metamorphism and igneous intrusions. Locally there are effects of K-metasomatism in mylonitic zones. The volcanosedimentary sequences of the Rio das Velhas greenstone belt contain metaultramafic extrusive rocks (metakomatiites), amphibolites of basic lavas, mafic to metapelitic schist and various chemical metasediments. The metakomatiitic rocks show strong geochemical variability due to anisochemical processes that affected most analyzed elements, including some of the elements normally considered 
immobile: $\mathrm{Ti}, \mathrm{Nb}, \mathrm{Y}, \mathrm{La}, \mathrm{Ce}, \mathrm{Nd}$, amongst others. The metabasic amphibolites were characterized as derived from tholeites of olivine normative to quartz normative compositions, ocean floor characteristics, that were formed probably in a retro-arc basin. Occasionally one notices hydrothermalmineralizing processes (pre-metamorphic), due to positive anomalies of LREE, $\mathrm{Zr}$ and base metals, amongst others. The Proterozoic Espinhaço metasediments, are the southernmost occurrences of this Supergroup yet confirmed in Minas Gerais State, including amongst others, lithologies typical of the Sopa Brumadinho and Galho do Miguel formations. The metasediments of the Lower Proterozoic Minas Supergroup, are quantitatively not expressive in the studied Quadrangle and characterized by quartzhematitic itabirites, with associated high grade hematite ores of the Itabira Group, Caue Formation. Its deformation and metamorphic states when compared to the Espinhaço Supergroup indicate allochthonous origin, of pre-metamorphic nappes, for the Minas Supergroup in the Bateias Quadrangle. Evidences of relative age differences and/or in terms of orogenic cycles between the metasediments of the Espinhaço and Minas supergroups have not been found; therefore they have been included in a single orogenic cycle, the Minas/Espinhaço Cycle, considered to be of Lower to (?) Middle Proterozoic age.

The metabasic rocks/amphibolites of the Basic Subvolcanic Suite intrude all Precambrian units in the studied area, yet they have not been found in the Minas Supergroup. These rocks were also affected by the regional metamorphism of the Minas/Espinhaço Cycle. Petrologically they are continental tholeiites. All are hypersthene normative, ranging from quartz to olivine normative.

The Bateias Quadrangle has in general polymetamorphic characteristics. Outstanding are the barrovian nature, of intermediate pressure with kyanide, the polarity increasing from $\mathrm{W}$ to $\mathrm{E}$ from the upper green-schist to (?) middle amphibolite fácies, of the main regional proterozoic tectonothermal event of the Minas/Espinhaço Cycle.

Later geological processes include events of retrometamorphism, fracturing, uplift and erosion, since the precambrian, some of wich are related to the Brasiliano Cycle, up to fanerozoic.

FRASCÁ, Maria Heloisa Barros de Oliveira

Petrografia e geoguimica de rochas carbonáticas pré-cambrianas do Estado de São Paulo. 29 de março. 168p. Orientador: José Moacyr Vianna Coutinho.

Resumo: As rochas carbonáticas pré-cambrianas do Estado de São Paulo ocorrem na forma de grandes corpos alongados segundo NE-SW, em sequências supracrustais do Grupo Açungui (sensu lato), principalmente nos Subgrupo Lajeado e Formaçăo Itaiacoca, e Grupo São Roque. Corpos de menor expressão constituem o Mármore da Tapagem e ocorrências esporádicas nos Complexo Embu, Grupo Itapira, Complexo Piracaia, Formação Setuva e Formaçăo Água Clara.

Neste trabalho, foram efetuados estudos petrograficos, quimicos, isotópicos e de caracterização tecnológica em amostras de rochas carbonáticas coletadas nas unidades geológicas mencionadas.

As rochas aqui estudadas apresentam composição ora essencialmente calcítica (Subgrupo Lajeado e Grupo São Roque - região de Salto de Pirapora), ora essencialmente dolomitica (Formação Itaiacoca c Grupo São Roque - região de Pirapora do Bom Jesus). Nas outras unidades predominam litotipos de composiçōes intermediárias, ora dolomito-calcíticas, ora calcíto-dolomíticas.

As rochas carbonáticas dos grupos Açungui e São Roque normalmente exibem paragêneses indicativas de metamorfismo de grau baixo. Todavia, na Formaçăo Água Clara, são observadas associaçōes minerais de metamorfismo de grau médio. Já as rochas carbonáticas dos complexos Embu e Piracaia e Grupo Itapira foram submetidas a metamorfismo de grau alto, localmente mostrando metamorfismo de contato superimposto.

As caracteristicas geoquimicas exibidas pelas rochas dolomiticas são bastante 
semelhantes entre si, em geral com valores minimos para os elementos menores e traços analisados, sobretudo Mn e Sr. Os dolomita mármore do Grupo São Roque podem ser claramente discriminados pelo seu maior teor de Mn e Fe, aparentemente refletindo um processo de dolomitizaçâo via dissoluçăoreprecipitação a partir de sedimento calcitico. Os baixissimos teores de $\mathrm{Sr}$ dos metadolomitos da Formaçăo Itaiacoca sugerem que sua deposiçăo tenha se dado via protodolomita.

As rochas calcárias se dividem quimicamente em dois grupos. O primeiro (Subgrupo Lajeado e Grupo São Roque) é mais puro e rico em Sr. Os calcita mármores do Subgrupo Lajeado, em vista de sua riqueza em $\mathrm{Sr}$, aparentemente se depositaram na forma de lama aragonitica modificada diagenética ou metamorficamente para calcita ou calcita magnesiana. O segundo grupo (formaçōes Água Clara e Itaiacoca) é rico em Mn, Rb, Fe, Ba c Al, refletindo uma maior contribuiçâo terrigena.

As composições isotópicas de carbono e oxigênio das rochas carbonáticas estudadas são caracteristicas de carbonatos marinhos pré-cambrianos metamorfizados. Dentro de uma mesma unidade geológica, as composiçôes isotópicas de carbono mostram certas variaçōes que se explicariam por mudanças locais no ambiente de sedimentação. A homogeneidade das composiçōes isotópicas de oxigênio em cada unidade geológica parece refletir a contemporaneidade da formaçâa dos litotipos carbonáticos.

As rochas carbonáticas aqui estudadas teriam se originado em bacias ensiálicas desenvolvidas a partir de sistema de riftes. As sequências sedimentares dos grupos Açungui e São Roque poderiam ter se formado $\mathrm{em}$ bacias distintas, talvez năo sincrônicas.

Após comparação dos resultados de ensaios tecnológicos e dos dados químicos com especificações de uso das rochas carbonáticas detectou-se outras op̧̣̃ées de aplicaçōes, além daquelas para as quais são ou foram exploradas. Citam-se, como exemplo, as rochas carbonáticas do Grupo São Roque que têm seu uso voltado quase que exclusivamente para o mercado convencional (cimento, cal e corretivo de solos) e que poderiam ser igualmente aproveitadas nas indústrias do vidro e cerâmica.

Abstract: The Precambrian carbonate rocks in the State of São Paulo occur as large NE-SW elongated bodies inserted in the supracrustal sequences of the São Roque and Açungui Groups (specially Lajeado Subgroup e Itaiacoca Formation). Less significant bodies constitute the Tapagem Marble and sporadic occurrences in the Embu Complex, Itapira Group, Piracaia Complex and Setuva and Água Clara Formations.

Petrographic, chemical and isotopic studies as well as technological characterization were accomplished on samples of the above mentioned units.

The rocks under consideration show compositions sometimes mainly calcitic (Lajeado Subgroup and São Roque Group - region of Salto de Pirapora) sometimes essentially dolomitic (Itaiacoca Formation and São Roque Group - region of Pirapora do Bom Jesus). In the remaining unities, lithotypes of intermediate composition now dolomite calcitic, now calcite dolomitic, predominate.

The paragenesis of carbonate rocks from the Açungui and Sảo Roque Groups indicate low grade metamorphism. However, in the Água Clara Formation the observed mineral associations belong to the medium grade metamorphism. On the other hand, the carbonate rocks of Embu and Piracaia Complexes as well as those from the Itapira Group were subjected to a high metamorphic grade sometimes accompanied by superimposed contact metamorphism.

The geochemical characteristics of the dolomites are rather similar among themselves. It was noticed that they usually show smaller values for minor and trace elements, $\mathrm{Mn}$ and $\mathrm{Sr}$ above all. The São Roque dolomite marbles can be clearly discerned by their larger content of $\mathrm{Mn}$ and $\mathrm{Fe}$, an apparent indication of dolomitization by dissolution-reprecipitation processes in a calcitic sediment. The least content of $\mathrm{Sr}$ in metadolomites from the Itaiacoca Formation suggests a deposition via protodolomite.

The limestones can be chemically divided in two groups. The first one (Lajeado Subgroup e São Roque Group) is purer and richer in Sr. By its highest Sr content, the calcite marbles of 
the Lajeado Subgroup were possibly precipitated as an aragonitic mud diagenetically or metamorphically changed to calcite or magnesian calcite. The second one (Água Clara and Itaiacoca Formations) abounds with $\mathrm{Mn}, \mathrm{Rb}, \mathrm{Fe}, \mathrm{Ba}$ and $\mathrm{Al}$ implying a bulky terrigenous contribution.

The carbon and oxygen isotopic compositions for samples of studied carbonate rocks are diagnostic of metamorphosed Precambrian marine carbonates. The carbon isotopic compositions reveal some variation within the same geologic unit; they may reflect local changes in the sedimentary environment.

The homogeneity of the oxygen isotopic compositions in each geologic unit seem to manifest the coeval building up of the carbonate lithotypes.

The carbonate rocks, here studied, were probably generated in ensialic basins developed from rift systems. The sedimentary sequences of the Açungui and São Roque Groups might have been formed in independent basins, possibly not synchronous.

By comparing results of technological and chemical essays with specifications for the employment of carbonate rocks, other uses besides those for which they are being exploited, were detected. As an example, the São Roque Group carbonate rocks currently worked for the conventional market (cement, lime, soil corrective) could also have a profitable use in ceramics and in glass industry.

\section{GIMENEZ FILHO, Antonio}

Evoluçāo do complexo granitico Très Córregos a noroeste de Apiai - SP. 17 de maio. 132p. Orientador: Wilson Teixeira.

Resumo: Uma porção do Complexo Granítico Três Córregos no sul-sudoeste do Estado de São Paulo, com mapa geológico na escala 1:50.000 já disponível, foi objeto de investigaçōes de cunho geocronológico e litoquimico. Estes mapas foram modificados e reinterpretados de forma integrada, sendo apresentados na escala 1:100.000.

O objetivo principal dos estudos foi a caracterizaçăo da evolução do complexo e contribuir para o debate quanto a sua colocaçăo tectônica. Já as unidades metassedimentares existentes na área (do Complexo Metamórfico Apiai-Mirim, Formação Água Clara, Grupo Itaiacoca e Formaçāo Córrego dos Marques) nâo foram objeto dos estudos.

Foram realizadas 53 determinaçöes $\mathrm{Rb}-\mathrm{Sr}, 15 \mathrm{~K}-\mathrm{Ar}$ e duas análises experimentais pelo método U-Pb (zircōes). Os estudos litoquimicos envolveram a interpretação dos dados de 40 análises de elementos maiores e traços, além de 10 análises de elementos terras-raras.

As principais modificaçoes quanto à cartografia das unidades referem-se ao Complexo Metamórfico Apiai-Mirim. Dois conjuntos litológicos anteriormente nele admitidos (ortognaisses e migmatitos) foram redefinidos. Os ortognaisses foram admitidos como Granitóides Orientados e incluidos, devido às semelhanças petrográficas, geoquímicas e padrão geocronológico, no Complexo Três Córregos. Os migmatitos foram subdivididos, sendo parte incluida nos Granitóides Orientados, parte admitida como Granitóides de Anatexia/Migmatitos e parte destacada como augen gnaisses. As duas primeiras foram incluidas no Complexo Três Córregos e, a última, interpretada como megaenclave englobado por este complexo.

Três principais unidades geológicas com caracteristicas petrográficas, geoquímicas e geocronológicas distintas foram caracterizadas: a. Augen Gnaisses; b. Complexo Granitico Três Córregos; e c. Suite Granitica Pós-Tectônica.

Os augen gnaisses, juntamente com gnaisses finos que săo seus enclaves (ambos de composição quartzo diorítica a quartzo monzodiorítica), apresentam comportamento geoquímico anômalo em relaçáo às rochas o Complexo Très Córregos. Idades $\mathrm{Rb}-\mathrm{Sr}$ obtidas nos gnaisses finos (ca. $1,8 \mathrm{Ga}$ ), foram as mais antigas obtidas neste trabalho. Um resultado $\mathrm{U}-\mathrm{Pb}$ preliminar $\mathrm{em}$ augen gnaisse sugere idade também antiga. 
No Complexo Granítico Três Córregos foram incluídos quatro conjuntos litológicos: 1.Granitóides de Anatexia/Migmatitos; 2. Granitóides Orientados; 3. Suite Porfiróide; e 4. Granito Lajeado. O primeiro conjunto não foi objeto de estudos experimentais. $\mathrm{O}$ segundo apresenta caracteristicas petrográficas, geoquimicas e padrão geocronológico muito semelhantes ao terceiro. Este (Suite Porfiróide) 6 o de maior expressão $\mathrm{em}$ área, sendo composto pelos granitos Barra do Chapéru, Saival, Córrego do Butiá, Capote e Paiol de Telha. O Granito Lajeado (4) representa um pequeno corpo de granito microporfiritico existente em meio à área do Granito Barra do Chapéu.

Os granitóides do Complexo Três Córregos, objeto principal dos estudos, foram caracterizados como uma sequêencia calcioalcalina, básica-intermediária-ácida, de granitóides do tipo I Caledoniano ou de soerguimento tardi a pós-colisional. Tais caracteristicas são compatíveis com um ambiente de arco magmático tipo Andino (correlacionáveis a granitóides do Chile central). Os dados geocronológicos $\mathrm{Rb}-\mathrm{Sr}$ obtidos indicam para a atividade deste aroo o periodo entre 800 e $650 \mathrm{Ma}$ atrás, o que é corroborado por uma indicação preliminar de idade U-Po em zircāo. As altas razōes iniciais ${ }^{87} \mathrm{Sr} /{ }^{86} \mathrm{Sr}$ obtidas são ilustrativas de processos de contaminaçâo crustal na gênese deste complexo.

O padrăo das idades aparentes $\mathrm{K}-\mathrm{Ar}$ a nivel regional permitiu indicar o intervalo temporal entre 625 e $600 \mathrm{Ma}$ como do resfriamento relacionado ao soerguimento e estabilização do Ciclo Brasiliano.

A Suite Pós-Tectônica é constituída, na área, pelos Granitos Correas e Sguário. 0 Granito Campina do Veado, fora da área, correlacionado a estes, foi também estudado, Sð̃o granitos fortemente diferenciados e caracterizados, geoquimicamente, como do tipo intraplaca, formados por fusăo crustal. Os dados Rb-Sr obtidos indicaram idade cambro-ordoviciana (480-520 Ma), surpreendentemente mais jovens que as idades $\mathrm{K}-\mathrm{Ar}$ ( $564-596 \mathrm{Ma}$ ), as quais são aqui admitidas como mais realisticas para a idade de colocação destes corpos, em função dos altos erros das razōes iniciais ${ }^{87} \mathrm{Sr}{ }^{86} \mathrm{Sr}$ obtidas e da existência de metassomatismo nestes granitos.

Abstract: A portion of the Três Córregos Granitic Complex, south-southwest of the State of São Paulo, has been investigated in its geochronological and geochemical aspects. Previous geologic maps (1:50.000) that supported the field work were revised. adapted and integrated in a $1: 100,000$ scale map.

The main subject of the studies done was the characterization of the evolution of such a Complex leading to discussion of its tectonic setting. On the other hand metasedimentary sequences belonging to the Apiai-Mirim Complex, Água Clara and Córrego dos Marques Formations and Itaiacoca Group have been not investigated.

Fifty three $\mathrm{Rb}-\mathrm{Sr}$ (isochrons) and $15 \mathrm{~K}$-Ar age determinations and two experimental analyses by the U-Pb (zircons) method have been performed. The geochemical studies involved data interpretation of 40 analyses for major and trace elements and further 10 analyses for Rare Earth Elements. These data have been discussed together with published chemical data on granitoids of the study area.

The main rock units (migmatites and orthogneisses) exposed in the investigated area which have been considered previously as belonging to the Apiai-Mirim Complex are here excluded from this Complex, based on their geological inferences, controlled by petrographic, geochemical and geochronological data: The migmatites are subdivided and included in the "Oriented Granitoids", "AnatectioMigmatic Granitoids" and "Augen Gneisses". The formers are included within the Três Córregos Complex and the latter interpreted as a large enclave/xenolith within this Complex. The orthogneisses were considered as "Oriented Granitoids".

As general three main geological units have been emphasized in the studies: a) Augen Gneisses; b) Três Córregos Granitic Complex; c) Pos-tectonic Granitic Suite.

The Augen Gneisses together with the thin, dark gneisses enclaves (both of quartz dioritic to quartz monzonitic composition) showed anomalous geochemical pattern comparatively to the units of the Três Corregos Complex. The thin gneisses yielded $\mathrm{Rb}-\mathrm{Sr}$ isochron ages of $\mathrm{ca} .1,8 \mathrm{Ga}$ which 
are broadly comparable with one preliminary $\mathrm{U}-\mathrm{Pb}$ zircon age also performed in the augen gneisses.

To the Três Córregos Granitic Complex belong four lithological groups of rocks: 1) Anatetic/Migmatitic Granitoids (not studied); 2) Oriented Granitoids; 3) Porphiritic Suite (best exposed in the area), which is constituted by the Barra do Chapéu, Saival, Córrego do Butiá, Capote and Paiol de Telha Granites; and 4) Lajeado Granite, a small body within the Barra do Chapéu Granite.

Chemically, the plutonic rocks of the Três Córregos Complex are consistent with a calcalkaline sequence of basic-intermediate-acid character, corresponding to I-type Caledonian granitoids or tardi- to post-collisional uplift granitoids types. Those chemical features are compatible with that of an Andine arc magmatic tectonic setting. Radiometric data ( $\mathrm{Rb}-\mathrm{Sr}$ and $\mathrm{U}-\mathrm{Pb}$ ) indicate that such a plutonism took place between $800-650 \mathrm{Ma}$ ago. Isotopic evidences given by the high ${ }^{87} \mathrm{Sr} /{ }^{86} \mathrm{Sr}$ initial ratios obtained suggest that crustal contamination played and important role in the genesis of the rocks in coherence with the chemical data.

The age pattern given by the distribution of $\mathrm{K}-\mathrm{Ar}$ data in the investigated area may indicate that the regional cooling of the above proposed magmatic arc took place at the end of the Brasiliano Cycle, between $625-600 \mathrm{Ma}$ ago.

Finally, the Post-Tectonic Suite yielded K-Ar ages between 596 and $565 \mathrm{Ma}$. This Suite is represented by the Correas and Sguario granites, in the investigated area although other one body, the Campina do Vale Veado Granite, may be a correlative outside the area, as supported by its chemical trend. As a whole the Suite is chemically characterized by strongly differentiated rocks of intraplate type. The high ${ }^{87} \mathrm{Sr} /{ }^{86} \mathrm{Sr}$ initial ratios together with chemical data support a crustal origin for these rocks.

\section{IMBERNON, Rosely Aparecida Liguori}

Evoluçāo geoquimica e mineralógica dos produtos de alteração intempérica sobre as rochas do Complexo Alcalino-Carbonatítico de Catalâo I, Goiás. 12 de abril. 132p. Orientador: Sonia Maria Barros de Oliveira.

Resumo: O Complexo Alcalino-Carbonatitico de Catalão I situa-se no estado de Goiás, a aproximadamente $280 \mathrm{~km}$ ao sul de Brasilia.

Constitui-se num corpo semicircular com cerca de $6 \mathrm{~km}$ de diâmetro. Compöe, juntamente com os Complexos de Araxá, Cataläo II, Salitre I e II e Tapira, um grupo de complexos alcalinos pertencentes à provincia de Alto Paranaiba, que intrudiram em metassedimentos proterozóicos do Grupo Araxá.

As rochas frescas são principalmente glimmeritos cortados por veios carbonatiticos, podendo ocorrer restritos corpos de piroxenito e peridotito. Anatásio, vermiculita, minerais de terrasraras, apatita e pirocloro são os principais minerais de interesse econômico relacionados à intrusăo carbonatitica.

A açăo do intemperismo foi bastante intensa sobre o complexo. O relevo do maciço foi mantido graças à resistência das rochas quartziticas fenitizadas que o circundam, o que permitiu 0 aprofundamento dos perfis de alteração que podem chegar a mais de 100 metros de espessura no centro do complexo. É um processo tipicamente lateritico que gerou concentraçōes residuais de apatita e pirocloro nos niveis intermediários do perfil de alteração. Esses minérios são atualmente explorados.

Os ETR foram concentrados pelo hidrotermalismo, constituido por materiais silicificados ricos em monazita. Também o intemperismo concentrou esses elementos na forma de fosfatos aluminosos secundários do grupo da plumbogumita e florencita.

A intensa silicificaç̃o observada no complexo é em sua grande parte de origem hidrotermal. Ocorre, localizadamente, silicificaçăo intempérica em certos horizontes do perfil de alteração. 
Abstract: The Alkaline-Carbonatite Complex of Catalão I is located in the state of Goiás, approximately $280 \mathrm{~km}$ south of Brasilia. Together with the Araxá, Catalão II, Salitre I and II, and Tapira alkaline complexes within the Alto Paranaiba alkaline province. Catalåo I is a semi-circular body $6 \mathrm{~km}$ in diameter which intruded Proterozoic metasediments of the Araxa Group in the Cretaceous.

Principal rock types area glimmerites cut by carbonatites veins. Restricted bodies of pyroxenite and peridotite may also occur. Anatase, vermiculite, REE-bearing minerals, apatite, and pyrochlore are the main minerals of economic interest related to this carbonatitic intrusion.

Although intensely weathered, the complex is dome-shaped, its relief sustained by the resistance of the surrounding, fenitized quartzitic rocks, which also permitted weathering profiles to reach more than 100 meters in depth.

Typical lateritic processes generated residual concentrations of apatite and pyrochlore at intermediate levels of the weathering profile. These are presently being exploited. Rare earth elements are concentrated in monazite in hydrothermally silicified horizons and in secondary aluminous phosphates of the plumbogummite and florencite groups by weathering. Most of the silicification observed in the complex is of hydrothermal origin. Weathering silicification occurs locally in alteration levels.

It's a semi-circular body with $6 \mathrm{~km}$ of diameter. Put together with the Araxá, Catalăo II, Salitre I and II and Tapira complexes, a group of alkalin complexes which belong to Alto Paranaiba province, which intruded in Proterozoics metasediments of the Araxá Group.

The fresh rocks are essentially glimmerites crossed by carbonatites veins, pyroxenites and peridotites restricted bodies may also occur. Anatase, vermiculite, REE bearing minerals, apatite and piroclore, are the main minerals of economic interest related to carbonatitic intrusion.

The weathering action was intensive over the complex and the massive relief was sustained by the resistance of the fenitized quartzitics rocks which surround it, what permitted the deepening of the weathering profiles which can reach more than 100 meters of thickness in the complex centre.

It's a typical lateritic process which generate residual concentrations of apatite and piroclore in the intermediary levels of the weathering profile, which constitute natural deposits and are presently explorated.

Minerals bearing REE are concentrated with monazite, associated at silicified horizonts, and secoundaries aluminous phosphates of the plumbogummite and florencite group.

The great silicification observed in the complex is mostly of hydrothermal origin. Weathering silification occurs locally in alteration levels.

\section{IRITANI, Mara Akie}

Potencial hidrogeológico da Cidade Universitária de Săo Paulo. 13 de maio. 149p. Orientador: Aldo da Cunha Rebouças.

Resumo: A Cidade Universitária, situada na zona oeste do Municipio de São Paulo, com uma demanda mensal de $240.000 \mathrm{~m}^{3}$ de água, procurou meios alternativos à rede pública de abastecimento, optando pela exploração dos recursos hídricos subterrâneos como fonte complementar.

Aproveitando a oportunidade, foi feito este estudo visando caracterizar o potencial hidrico do aquifero sedimentar, composto por areias e conglomerados intercalados por lentes de lamito, pertencentes à Bacia Sedimentar de São Paulo.

Para tanto, instalou-se uma rede de poços de monitoração e multiniveis para a observaçăo do comportamento do aqüifero, que mostra um fluxo da água subterrânea em sentido ao rio Pinheiros.

Os perfis geológicos dos poços, associados às informaçбes geofisicas, permitiram definir 
a geometria do aqüifero sedimentar, que se espessa na porção norte da Cidade Universitária. As maiores espessuras săo encontradas numa faixa E-W passando pela Raia Olímpica e a Escola Politécnica.

O teste hidrodinâmico realizado no poço produtor PPI evidenciou um comportamento com tendência ao semiconfinamento, com valores de transmissividade entre $10^{-4}$ e $10^{-3} \mathrm{~m}^{2} / \mathrm{s}$ e de condutividade hidráulica entre $10^{-6} \mathrm{e} 10^{-4} \mathrm{~m} / \mathrm{s}$. O coeficiente de armazenamento mostrou menores valores a maiores profundidades, variando de $10^{-4}$ a $10^{-1}$.

Estes dados permitiram avaliar as reservas permanentes e reguladoras que mostraram altos valores. A reserva permanente é da ordem de 11 milhöes de $\mathrm{m}^{3}$, enquanto a reserva reguladora ultrapassa os $900 \mathrm{mil} \mathrm{m}^{3} / \mathrm{ano}$, volume este duas vezes superior ao volume produzido pelos poços produtores no aquífero sedimentar.

Estes resultados evidenciam o potencial produtivo favorável do aquifero na área de estudo, sendo que as análises de água realizadas mostraram-se dentro dos padrōes de potabilidade.

Entretanto, devido à má qualidade da água do rio Pinheiros, um estudo mais aprofundado sobre a relaçåo com a água superficial deve ser realizado para evitar a contaminação do aquifero.

Abstraet: The São Paulo University Campus, in the west of São Paulo Municipality, which consumes $240.000 \mathrm{~m}^{3}$ of water per month, has tried other water supply alternatives, such as groundwater.

This study aims the characterization of the sedimentary aquifer hydric potential, which is composed by sands and conglomerates interlayed by mudstone lenses of the São Paulo Sedimentary Basin. A net of monitoring wells and multilevels was installed in order to study the aquifer behavior. Well monitoring made evaluation of ground water flux towards Pinheiros River possible.

The association of geologic sections with geophysical information enabled the definitions of the sedimentary aquifer geometry, which thickens in the northern part of the University Campus. Maximum thickness were found in a E-W belt passing through Raia Olimpica and Escola Politécnica.

A hydrodynamic test performed in the productive well PP1 showed a semi-confinement tendency, with transmissivity and hydraulic conductivity values between $10^{-4}$ and $10^{-3} \mathrm{~m}^{2} / \mathrm{s}$ and $10^{-6}$ and $10^{-4} \mathrm{~m} / \mathrm{s}$ respectively. The storage coefficients decrease with greater depths, varying between $10^{-4}$ and $10^{-1}$.

With these data, permanent and regulating reserves were estimated, the former of 11 million $\mathrm{m}^{3}$ and the latter over 900 thousand $\mathrm{m}^{3} / \mathrm{year}$, twice as much as the volume produced by the productive wells in the sedimentary aquifer.

These results put in evidence the favorable productive potential of the aquifer in the study area. Water analysis proved it to be within potability standards.

It is important to point out that, due to the bad quality of the Pinheiros River water, a more detailed study on surface water flow should be carried out to avoid aquifer contamination.

\section{MELLO, Fernando Machado de}

Contribuiçāo à geologia estrutural da Unidade Porongos na sua localidade tipo: regiāo de Pinheiro Machado, Rio Grande do Sul. 01 de outubro. 122p. Orientador: Rômulo Machado.

Resumo: São aqui điscutidos os resultados de uma investigaçăo geológica realizada numa área de rochas metamórficas afetadas pela deformação brasiliana, situada na poçāo centro-sul do Estado do Rio Grande do Sul. O trabalho compreendeu a cartografia geológica básica em escala de semidetalhe de uma área de aproximadamente $500 \mathrm{~km}^{2}$, que engloba diferentes litologias definidas como Série Porongos, por Carvalho (1932).

A investigaçăo esteve centrada nos granitos deformados e suas relaçōes com uma 
cobertura metassedimentar. Na área de mapeamento foi identificado um evento de cavalgamento de um "lençol" cristalino (aqui denominado de unidade Granito-Gnáissica) sobre uma sequéncia miogeoclinal, interpretada neste trabalho como a extensão brasileira do Grupo Lavalleja (Bossi et al., 1967) do Uruguai. No curso da deformaçăo as rochas graniticas sofreram um processo de cominuição e transformação mineral, sob um regime de deformação não co-axial, em condiçães dúcteis, em que ocorreu uma expressiva segregação de silica, que gerou em alguns casos dezenas de metros de espessura de quartzo-milonitos.

O estudo é fundamentado nos aspectos mineralógicos, petrográficos, estratigráficos, estruturais e, especialmente, na microtectônica. Atenção especial foi dedicada à caracterização dos diferentes tipos de lineaçōes e foliações, assim como nas análises geométrica e cinemática com base no conceito de dominios homogêneos.

A deformação iniciou-se por uma fase de tectônica compressiva, com a geração de um sistema de cavalgamentos, vergentes para NNW. Neste estágio, foram geradas estruturas do tipo "duplex", leques imbricados e dobras recumbentes, em zonas de cisalhamento de baixo ângulo, num contexto de uma rampa obliqua, provavelmente associada à uma zona de detachment. Neste primeiro grupo de estruturas a deformação foi predominantemente dúctil e não co-axial. Na sequuência da deformação houve, no minimo, mais dois eventos, que promoveram o redobramento das estruturas anteriores, acompanhado de generalizado falhamento e fraturamento na área, em condiçōes essencialmente rúpteis.

Abstract: Research was carried out on the rocks affected by the brasiliano episode of deformation, in the Uruguaio-Sul-rio-grandense shield, localized in state of Rio Grande do Sul, Brazil. An area about $500 \mathrm{~km}^{2}$, situated in the lithologies defined as the Porongos Series was mapped.

The investigation was centered on the deformed granites and their relationship with a metasedimentary cover. In the map area there was one main event of thrusting of an crystalline sheet, in this work called the Granito-Gnaissico unit, over a miogeoclinal sequence, thought to be related to the Lavalleja Group, in Unuguay. On the course of the deformation the granite rocks suffered a large process of conminuition and mineral transformations, under a ductile regime, with expressive segregation of silica, sometimes with generation of tens of meters of quartz-mylonites.

The study comprises mineralogical and petrographic aspects with particular emphases on microtectonic. In the field work, special attention was given to define the kinds of foliations and lineations, to characterize the kinematic pattern in the region.

The successive deformation was initiated by a period of compressive tectonics, with generation of a thrust system with a vergence to NNW, formed by duplex, imbricate fans and recumbent folds, within an oblique ramp, probably associated to an detachment zone. In this first group of structures the deformation was ductil and non-coaxial. In sequence, there were, at least two more events, which caused refolding the older structures and generalized faulting and fracturing in the area, in brittle manner.

\section{MOTIDOME, Mário Juiti}

Geologia do Complexo-Embu na região entre Santa Isabel e Biritiba-Mirim, SP. 05 de março. 173p. Orientador: Georg Robert Sadowski.

Resumo: O mapeamento de uma faixa de $38 \times 18 \mathrm{~km}$ entre Santa Isabel e Biritiba Mirim (centroleste de São Paulo) permitiu o reconhecimento dos Complexos Rio Capivari, Pilar e Embu, limitados entre a Zona de Cisalhamento do Rio Jaguari (Falha de Jaguari/Monteiro Lobato) e a Zona de Cisalhamento de Cubatão.

A Zona de Cisalhamento de Guararema divide esta àrea em dois grandes blocos, ao 
norte localizam-se os Complexos Rio Capivari e Embu, e ao sul o Complexo Pilar.

O Complexo Rio Capivari é constituido por hornblenda biotita gnaisses de composição tonalítica, de estrutura centimetricamente bandada a homogenea. Encontra-se migmatizado por leucossomas brancos de composiçāo trondhjemitica com anfibólio, e leucossomas rosados de composição granítica, com e sem anfibólio.

Este conjunto, embora de idade do Proterozóico Inferior/Arqueano, mostra igual número de fases de deformação que as sequêencias supracrustais dos Complexos Pilar e Embu.

O Complexo Pilar é constituido essencialmente por metassedimentos pelíticos e pelitopsamíticos, além de rochas calciossilicáticas e possiveis ortognaisses de composição granodioritica. A rocha volumetricamente mais importante corresponde a muscovita biotita xisto e, subordinadamente granada biotita xisto.

O Complexo Pilar apresenta cerca de quatro fases de deformaçăo sendo as três primeiras sinxistosas. A foliação principal $\left(\mathrm{S}_{2}\right)$ é marcada por achatamento de grãos de quartzo c principalmente pela orientação de micas. O metamorfismo principal ocorreu em condiçôes de fácies xisto verde, zona da granada a biotita, embora regionalmente sejam relatadas cianita c estaurolita.

Rochas granitóides associadas ao Complexo Pilar são biotita granitos porfiróides (Granitos Itapeti e Santa Catarina) e granitos a duas micas (Granitos Mogi das Cruzes e Sabaúna, eventual portador de granada).

Um terceiro tipo de granito que ocorre na área do Complexo Pilar e espacialmente associado à Zona de Cisalhamento de Guararema corresponde a turmalina leucogranitos brancos designados de Bairro dos Nogueiras, que formam pequenos corpos alongados.

Foram individualizadas cerca de sete unidades de mapeamento no Complexo Embu, constituido basicamente por prováveis biotita ortognaisses microporfiróides e biotita gnaisses aluminosos/xistos. Estas unidades foram tentativamente empilhadas segundo a principal superficie tectônica, a xistosidade $S_{2}$.

Apresenta quatro fases de deformação, as três primeiras sinxistosas. As duas primeiras foliações geraram-se em fácies anfibolito alto marcada pela formação de sillimanita e feldspato potássico. A terceira fase de deformação caracteriza-se por recristalização de biotita.

Rochas granitóides intrusivas no Complexo Embu foram separadas em cinco tipos. Três destes foram analisadas quimicamente e apresentaram composiçóes quartzo-monzoniticas, granodioriticas e graniticas. Elementos terras-raras indicam fontes magmáticas distintas para os três tipos de granitóides.

A história metamórfica e a associação de rochas granitóides distintas dos Complexos Pilar e Embu, sugerem que estes complexos não sejam correspondentes, embora estruturalmente semelhantes. Dados geocronológicos disponíveis indicam idades do Proterozóico Médio para a sedimentaçăo do Complexo Pilar e metamorfismo principal a cerca de $750 \mathrm{Ma}$.

Embora carecendo de melhor caracterização geocronológica, o Complexo Embu apresenta idades limitadas ao Proterozóico Superior e o evento metamórfico principal é algo mais jovem (730 Ma) que o do Complexo Pilar.

Abstract: Geological mapping of an area between Santa Isabel and Biritiba-Mirim (East of São Paulo State), measuring $38 \times 18 \mathrm{~km}$, bounded to the North by Rio Jaguari Shear Zone and to the South by Cubatāo Shear Zone, showed the occurrence of Rio Capivari, Pilar and Embu Complexes.

Guararema Shear Zone which runs approximately East-West divides that area in two, in the Northern part crop out rocks of Rio Capivari and Embu Complexes, and in the Southern portion rocks of Pilar Complex.

Rio Capivari Complex consists of hornblende biotite gneiss of tonalitic composition, of banded to homogeneous structure. It is cut by three kinds of leucossome, homblende bearing trondhjemitic white leucossome and granitic (with or without hornblende) pinkish leucossomes. 
This complex of Lower Proterozoic/Archean age, shows same deformation phases of the supracrustal rocks from Pilar and Embu complexes. Metamorphism responsible of migmatization took place possibly slightly above conditions of ordinary regional metamorphism.

Pilar Complex contains three mapping units. It mainly consists of pelitic to psamopelitic metasediments, but also calc-silicate rocks and granodioritic gneisses of probable igneous origin. Most important rocks are muscovite biotite schists and garnet biotite schists.

Pilar Complex shows four phases of folding, the last one has not generated an axial plane foliation. Main foliation is linked to the second phase and is characterized by flattening of quartz grains and the orientation of micaceous minerals. The sequence went through greenschist facies metamorphism, biotite to garnet zones, although regionally staurolite and kyanite have been reported.

Granitic rocks intruding Pilar Complex are porphyritic biotite granites (Itapeti and Santa Catarina granites) and two mica granites (Mogi das Cruzes and Sabauna, the last one a garnet bearding granite). A third kind of granite which is spatially related to the Guararema Shear Zone is a white tourmaline leucogranite named Bairro dos Nogueiras.

Seven lithological units have been defined in the Embu Complex, which consists of microporphyritic biotite orthogneiss and alumina-rich gneisses and schists. A tentative column of those units is based on the most pervasive structure $\mathrm{S}_{2}$.

Four folding phases were recognized, the first have generated a schistosity, which developed under upper amphibolitic facies (second isograd of sillimanite) and the third one under greenschist facies conditions.

Granitic rocks (s.1.) were separated into five types of granitoids. Three types were geochemically analised and showed quartz-monzonitic, granodioritic and granitic compositions. Rare Earth Elements (REE) indicates three different magma sources.

Metamorphic history and different igneous association suggest that Embu and Pilar Complexes are not similar, although show a very close structural history. Available geochronological data suggests a Middle Proterozoic age to the sedimentation of Pilar metasediments and main metamorphic event around $750 \mathrm{Ma}$. Although lacking better geochronological characterization Embu Complex suggests Upper Proterozoic ages, with main metamorphic event slightly younger (ca. $730 \mathrm{Ma}$ ) than Pilar Complex.

\section{NEUMANN, Reiner}

Contribuiçào à petrologia das rochas charnockíticas de Ubatuba, leste do Estado de Säo Paulo. 10 de setembro. 94p. Orientador: José Vicente Valarelli.

Resumo: Reconhecem-se, na região de Ubatuba (leste do Estado de São Paulo), pelo menos seis corpos lenticulares de $m$-charnockito, em geral em contato transicional com um hornblenda-biotita granito. O corpo maior aflora $\mathrm{em}$ aproximadamente $250 \mathrm{Km}^{2}$, o segundo $\mathrm{em} 12 \mathrm{Km}^{2}$, e os outros quatro em menos de $3 \mathrm{~km}^{2}$.

O charnockito apresenta-se como rocha de coloracaäo verde escuro, leuco- a hololeucocrática, equigranular a porfirítica de matriz média-grossa, geralmente pouco ou não foliada. Mineralogicamente, o charnockito compôe-se de ortoclásio micro- e mesopertítico, plagioclásio, por vezes antipertítico, quartzo, ferrohastingsita $c$ ortoferrossilita com zircão, apatita e opacos (magnetita c ilmenita) como minerais acessórios comuns. Biotita é frequéente, a hedenbergita pode ocorrer. Altanita e titanita são acessórios raros. A paragênese primária provavelmente foi ortoferrossilita + ortoclásio mesopertítico + plagioclásio antipertítico + quartzo + acessórios \pm hedenbergita, e a ferrohastingsita e biotita são resultantes de transformaçōes a partir dos piroxênios, assim como parte das lamelas de exsoluçăo da mesopertita se agnuparam e formaram gräos individualizados. A rocha classifica-se como $m$-charnockito, plotando-se as normas CIPW no diagrama QAP ao invés das modas. 
O hornblenda-biotita granito que em geral faz contato com o charnockito tem mineralogia similar, mas sem piroxênios. Apresenta-se geralmente mais foliado, com desenvolvimento de porfiroblastos de quartzo, e seus feldspatos tem tendências a expulsar as exsoluçōes; 0 ortoclásio apresenta transformaçōes para microclínio.

Os diagramas de tendência, para os elementos maiores, apresentam disposiçăo num único trend evolutivo, com decréscimo de todos os elementos, à excessão do potássio, com aumento de $\mathrm{SiO}_{2}$. Os elementos menores em geral năo definem tendência. O diagrama R1-R2 com campos definidos por Batchelor \& Bowden (1985) indica para as análises do charnockito de Ubatuba uma evoluçào decorrente de fusão parcial em ambiente geotectônico tardiorogênico. Alguns outros sistemas classificatórios comuns para granitóides não permitiram classificaçăo, mas na sua concepção não foram contemplados granitóides formados em ambiente tarditectônico.

A utilização combinada dos estudos microtermométricos e de quimismo mineral (geotermômetros e geobarômetros) permitiu estimar as condiçōes de cristalização em temperatura e pressão de, respectivamente, $850 \pm 50^{\circ} \mathrm{C}$ e $7.0 \pm 0.5 \mathrm{~kb}$, com $\mathrm{P}_{\text {fluidos }} \ll \mathrm{P}_{\text {total }}$, e $\mathrm{X}_{\mathrm{H} \sim \mathrm{O}}$ muito baixa. Os geotermômetros/geobarômetros baseados em feldspatos e anfibólio forneceram estimativas para $\mathrm{P}$ e $\mathrm{T}$ muito inferiores, corroborando seu reequilibrio ou formaçăo posterior.

A idéia de origem magmática para as rochas charnockíticas de Ubatuba, já definida por outros autores, merece amplo respaldo neste trabalho. Da mesma maneira, as dataçōes de Gasparini \& Mantovani (1979), entre outras, que fornecem idade de aproximadamente $550 \mathrm{Ma}$ para a formaçâo do charnockito, com evento retrometamórfico em aproximadamente $480 \mathrm{Ma}$, são compatíveis com o observado.

Desta forma, e levando em conta as afirmaçōes destes autores e de Siga et al. (1989) que sua assinatura isotópica revela derivaçăo de crosta continental, as rochas charnockiticas de Ubatuba devem representar uma situação de crosta continental duplicada no limite Proterozóico Superior Fanerozóico.

Abstract: Six lenses of $m$-charnockite could be recognized at the Ubatuba region, east of São Paulo State, mainly in transitional contact with an hornblende-biotite granite. The largest one crops out at about $250 \mathrm{~km}^{2}$, the second 12 , and the others less then $3 \mathrm{~km}^{2}$.

The charnockite is a dark-green coloured, leuco- to hololeucocratic rock, equigranular to porphiritic with medium to coarse grained matrix, and shows little or none foliation. Ir's mineralogy comprises micro- and mesoperthitic orthoclase, antiperthitic plagioclase (oligoclase), quartz, ferrohastingsite and orthoferrosilite. Biotite is quite common, and hedenbergite may occur. Zircon, apatite, magnetite and ilmenite are the main accessory minerals, and allanite and sphene are rare. The original paragenesis probably was mesoperthitic orthoclase, antiperthitic plagioclase, quartz, orthoferrosilite and the accessory minerals (with or without hedenbergite), and ferrohastingsite and biotite are due to secondary transformations of the pyroxenes. Related to this process, the exsolution lamellae from the mesoperthites migrated, originating plagioclase grains. Displaying CIPW normative analysis on the QAP diagram, the rock can be named $m$-charnockite.

The mineralogical composition of the hornblende-biotite granite is similar to the charnockite, but pyroxenes are absent. Generally the granite presents a stronger foliation, with quartz porphiroblasts, and the orthoclase is reordering its structure to triclinic microline.

Harker diagrams for the main elements show a single trend, the oxides content decreasing as silica increases, and only $\mathrm{K}_{2} \mathrm{O}$ increases with silica increasing. Minor elements don't display any trend. Batchelor \& Bowden's (1985) tectonic interpretation for the R1-R2 diagram indicate a late-orogenic, equilibrium partial melting controlled evolution for the charnockites, and other common discriminating systems failed in classifying it. This systems (Pearce et al., 1989; Maniar \& Piccoli, 1989) are not suitable for magmas generated in late-orogenic environment.

Fluid inclusion and geothermobarometric studies indicate crystallization temperatures 
and pressures of $850 \pm 50^{\circ} \mathrm{C}$ and $7.0 \pm 0.5 \mathrm{~kb}$, under $\mathrm{P}_{\text {fluids }}<<\mathrm{P}_{\text {total }}$, and low $\mathrm{X}_{\mathrm{H}_{2} \mathrm{O}}$. Feldspar and amphibole geothermometry/ barometry calculate lower $\mathrm{P}$ and $\mathrm{T}$ values, due to its secondary origin.

The magmatic origin for Ubatuba charnockites, as quoted by other authors, is supported by this work. Geochronological data from Gasparini \& Mantovani (1979) suits well to the observed features, and an age of about $550 \mathrm{Ma}$, with weak retrometamorphic event at about $480 \mathrm{Ma}$, can be accepted at time. A granitic magma generated by partial melting from upper crustal source rock and emplaced at the shown P-T conditions means that the Ubatuba charnockites represent a duplicated continental crust at the Phanerozoic-Proterozoic boundary.

\section{ORDÓÑEZ, Fernando Helí Romero}

Mineralogia, inclusōes fluidas e gênese de esmeraldas das jazidas de Chivar, Coscuez, Muzo, Pacho e Yacopi, Colómbia. 23 de novembro. 134p. Orientador: Darcy Pedro Svisero.

Resumo: As jazidas de esmeralda da Colômbia estão localizadas na parte central da Cordilheira Oriental, nas regiōes do Guavio e do Território Vásquez-Yacopi. Estas mineralizaç̋̋es de idade terciária, estâo localizadas em rochas sedimentares marinhas de idade cretácea inferior, pertencentes às unidades estratigráficas Calizas del Guavio e Lutitas de Macanal, ambas situadas na regiâo do Guavio, e às unidades Rosa Blanca e Paja, localizadas no Território Vásquez-Yacopi.

As caracteristicas de posicionamento das mineralizações esmeraldiferas sugerem um controle tectônico associado aos sitemas de falhas presentes nos anticlinais de Farallones e de Villeta Portones.

As esmeraldas ocorrem em bolsōes, nódulos e lentes, frequientemente relacionados a veios de calcita e brechas de falha em folhelhos carbonosos, siltitos e rochas carbonáticas.

Existem muitos problemas relacionados à gênese das mineralizaçōes, tanto no que se refere à idade, à origem e à composiçăo dos fluidos mineralizantes, bem como aos mecanismos de transporte e deposiçāo đo berilio.

Os valores dos parâmetros da cela unitária, dos indices de refração, da birrefrigência e da densidade relativa para as esmeraldas de Muzo, Pacho, Yacopi, Coscuez e Chivor, comparados entre si e com dados de outras localidades, mostram que os valores em questão divergem pouco entre si, denotando apenas pequenas diferenças nos processos genéticos entre os locais citados.

$\mathrm{Na}$ tentativa de fornecer alguma contribuição para o esclarecimento dos aspectos genéticos desses depósitos, foram realizados petrográficos das mineralizaçøes, microtermometria detalhada, espectroscopias micro-Raman e infravermelho, análises químicas e microscopia eletrônica de varredura das inclusōes fluidas nas esmeraldas estudadas. Para o reconhecimento das inclusōes cristalinas foram utilizados o microscópio eletrônico de varredura e difração de raios $\mathrm{X}$.

Os resultados dos estudos de microtermometria e espectroscopia micro-Raman em inclusōes fluidas permitiram definir os fluidos mineralizantes como soluçōes quentes (temperatura acima de $360^{\circ} \mathrm{C}$ ), de densidade média relativamente alta $\left(>1,10-1,20 \mathrm{~g} / \mathrm{cm}^{3}\right)$, e salinidades de $\mathrm{NaCl}$ equivalentes de 40 a $50 \%$ em peso, contendo $\mathrm{CO}_{2}$ (aproximadamente $0,2 \mathrm{~mol} \% \mathrm{em} \mathrm{Muzo}$, Pacho e Yacopi e aproximadamente $0,75 \mathrm{~mol} \%$ em Chivor) e pequenas quantidades de $\mathrm{N}_{2}$. Com relação às condiçōes de pressăo máxima, de formaçăo das esmeraldas estudadas, elas situam-se entre 1000 e 2000 bares.

Os estudos de raios X e microscopia eletrónica da varredura nas esmeraldas mostraram a ocorrência de incluső̀es cristalinas de cores claras e pequeno tamanho, entre as quais se incluem rutilo, calcita, dolomita, magnesita, pirita, quartzo, esmeralda, apatita, albita e matéria orgânica. Quase todos os componentes que formam as mineralizaçôes em veios, bolsốes, lentes, brechas e fissuras junto a esmeralda, apresentam-se, também, como inclusôes cristalinas, possivelmente como produto da interaçăo entre os fluidos mineralizantes $e$ as rochas preexistentes. 
As soluçöes mineralizantes sugerem uma origem a partir de águas conatas, meteóricas e, até mesmo, de águas que percolaram as falhas e circularam em niveis profundos, onde foram submetidas a aquecimento, surgindo ao longo de outras áreas de falhas. O estilo tectônico da área mineralizada desta região da Cordilheira Oriental, torna este modelo razoável. Tais águas conteriam oxigênio dissolvido que oxidou em parte hidrocarbonetos dos folhelhos negros nas áreas de brecha.

A fonte de $\mathrm{NaCl}$ e KCl para as salmouras observadas nas inclusões fluidas poderia ser encontrada nos corpos evaporiticos do Cretáceo Inferior, amplamente distribuidos nos Estados de Boyacá e Cundinamarca. Com relação ao $\mathrm{CaCl}_{2}$ existente nessas salmouras, a sua fonte poderia ser as águas marinhas que ficaram presas nos poros dos sedimentos e misturaram-se com águas meteóricas e conatas.

Com relaçăo à origem do berilio, admite-se fonte de origem marinha endógena profunda, considerando-se que as águas quentes, no seu processo de migração, solubilizaram o berilo existente nas rochas do embasamento da cordilheira $\mathrm{c}$, por percolação, conduziram esse elemento até a superficie.

Abstract: The emerald mines of Colombia are situated in the central part of the Eastern Cordilheira, specifically in the region of Guavio and Vásquez-Yacopi. These Be-mineralizations of Tertiary age found in Lower Cretaceous marine sedimentary rocks and belonging to the stratigraphic units "Calizas del Guavio" and "Lutitas de Macanal" (Guavio), as well as "Rosa Blanca" and "Paja" (Vásquez-Yacopi).

The field occurrence and geology of these mines imply a tectonic influence of a large fault system, evidenced by the anticlines of Farallones and Villeta Portones. The emeralds occur in voids, nodules and lenses, very often accompanied by veins of calcite and fault breccia in carbonaceous argillites, siltites and carbonates.

Cell parameters, density and optical properties of emeralds from Muzo, Coscuez, Pacho, Chivor and Yacopi have been determined and compared with data for other emeralds worldwide. There are hardly any differences in these properties between Colombian emeralds and others elsewhere.

To unravel the conditions of formation, fluid and solid inclusions have been investigated by IR and micro-Raman spectroscopy, X-ray diffraction, chemical means and electron microscopy.

The fluids were included as hot solutions $\left(>380^{\circ} \mathrm{C}\right)$, of relative high density $(1,20-1,22$ $\mathrm{g} / \mathrm{cm}^{3}$ ) and salinity (40-50 weight $\% \mathrm{NaCl}$ equiv.). The $\mathrm{CO}_{2}$ content is low $(0,2$ mole $\%$ in Muzo, Pacho and Yacopi and about 0,75 mole \% in Chivor) and nitrogen content is even lower.

Rutile, calcite, dolomite, magnesite, pyrite, quartz, emerald, apatite, albite and carbonaceous matter have been found as solid inclusions. Nearly all minerals and components of the host rock occur as solid inclusions, most probably due to rock-fluid interactions during the formation of the emeralds.

It is proposed that connate and meteoric waters penetrated deeper lying strata. After heating and leaching of chemical elements, these solutions ascended along deep fault systems. The tectonic style of the "Cordilheira Oriental" makes such a model likely.

The $\mathrm{NaCl}$ and $\mathrm{KCl}$ found in the brines of the fluid inclusions may have been derived from Cretaceous evaporites widely distributed in the states of Boyacá and Cundinamarca. The $\mathrm{CaCl}_{2}$ component may be derived from pore-waters in the sediments which mixed with the descending connate and meteoric waters. The $\mathrm{Be}$ is thought to have been derived by deep marine/crustal processes and transported by circulating waters to higher levels of the crust.

\section{RODRIGUES, Gilson Lucio}

Efeitos ambientais na produção de brita em áreas urbanas (poluição atmosférica $e$ vibração). 26 de abril. 78p. Orientador: Uriel Duarte. 
Resumo: A mineração quando tecnicamente mal conduzida ocasiona problemas ambientais tais como poluiçăo (água, ar e solo), vibraçđ̃o, ruido, ultralançamento de fragmentos, devastação de áreas, etc.

Nas regióes metropolitanas, devido à falta de um planejamento de uso e ocupação territorial, a proximidade das áreas de mineração com as áreas habitadas já é um fato.

Desta forma, o convivio entre a produção econômica de brita, a segurança e bem-estar à produçäo é fundamental, haja visto a necessidade predominante deste bem mineral.

Assim, procuramos expor neste trabalho a possivel convivência entre a mineração e sua vizinhança, desde que tenhamos a adoção de técnicas adequadas por parte do empresário, e a aplicaçăo efetiva de normas e legislação por parte do Estado.

Abstract: Mining activities, when technically bad conducted, cause environmental troubles like pollution (water, air and soil), vibrations noise, fragment overthrow, devastations, etc.

In the metropolitan areas, due to the lack of a land use planning, the proximity of the mining areas with houses is, indeed, a reality.

Therefore, the coexistence of the economic production of crushed granite mines, the safety conditions and welfare of the people is of essential concern because of the widespread use of that product.

This work shows that reasonable living conditions near mining sites is possible, once adequate technics are used by the mining company and proper legal rules and sanctions are effectively enforced by the government.

\section{RODRIGUEZ, Sergio Kleinfelder}

Neotectônica e sedimentação quatemária na regiāo da "Volta Grande" do rio Xingu, Altamira, PA. 30 de julho. $106 \mathrm{p}$. Orientador: Kenitiro Suguio.

Resumo: A área de estudos situa-se na porção central do Estado do Pará, no Município de Altamira, perfazendo $6.300 \mathrm{~km}^{2}$. Nesta regiāo estão localizados os mais importantes sitios projetados para a implantaçåo de usinas hidrelétricas do rio Xingu.

A patir de informaçōes referentes aos estudos geológico-geotécnicos para a elaboração do projeto denominado "Complexo Hidrelétrico de Altamira", somadas aos dados de campo obtidos pelo autor entre 1986 e 1989, além da análise morfoestrutural em produtos de sensoreamento remoto e em cartas topográficas, foi possivel a identificaçăo de evidências de movimentaçб̋es neotectônicas na área de estudos.

Os poucos trabalhos publicados sobre os depósitos quaternários continentais, em especial na Amazônia, fez com que durante a claboraçăo deste estudo, fosse sentida a necessidade de desenvolver uma metodologia apropriada para a caracterização das evidências neotectônicas estudadas em um contexto regional. Desta forma, destaca-se a análise dos gradientes hidraulicos das drenagens de $2^{a}$ ordem como um produto que possibilitou a identificaçăo, juntamente com a análise dos lineamentos morfoestruturais, de quatro sistemas de lineamentos principais, denominados de Paratizinho, Santo Antônio, Paxamba e Cachoeira Grande. Estes sistemas de lineamentos, ao interseccionarem o rio Xingu, marcam diferenças na morfologia das ocorrências dos depósitos quaternários.

É proposto um modelo evolutivo para o rio Xingu através de condições neotectônicas. interpretando-se, assim, a causa do desvio do curso do rio na forma de um grande arco voltado para sudeste, entre as cidades de Altamira e Belo Monte.

Os dados disponiveis permitem considerar toda a área em ascençåo durante o Cenozóico. Os lineamentos com direçōes $\mathrm{N} 80 \mathrm{~W}$ e $\mathrm{N} 40 / 30 \mathrm{~W}$, caracteristicos no curso do rio Xingu, sugerem a existência de compressão segundo NW e extensão segundo NE. Desta forma, as estruturas NW 
observadas em áreas com variaçāo lateral brusca de espessura de sedimentos quaternários, estariam representando reativaçōes neotectônicas destas descontinuidades em sistemas de falhas normais.

Estes esforços neotectônicos poderiam estar representando uma resultante das tensôes intraplaca relativas à migraçåo das placas de Nazca, Cocos e Caribe sob a Placa Sul-Americana e a expansão na Cadeia Mesoceânica, ou ainda poderiam estar relacionados a uma condiçăo de isostasia do Cráton Amazônico devido aos acúmulo da carga sedimentar cenozóica na foz do rio Amazonas e nas bacias do Acre e Solimōes, e erosăo na regiāo compreendida pelos altos estruturais de Furus e Gunupá.

Como resultado de aplicaçăo, as características neotectônicas apontadas podem ser utilizadas no detalhamento das obras de engenharia ou na prospecção de materiais naturais de construçäo.

Abstract: On the basis of geological and geotechnical studies carried out as a part the "Altamira Hydroelectric Complex" project along the Xingu river (southeastern Amazon region, Brazil), geological data gathered by the author from 1986 to 1989 and morphostructural analysis of remote sensing products and topographic maps, it was possible to identify evidence of neotectonic movements in the area known as the "Volta Grande" of the Xingu river.

Because few papers have been published on Brazilian Quaternary continental deposits, specially on those of the Amazon region, it was necessary to develop a suitable method to characterize neotectonic evidence within the regional context of the study area.

The principal results were derived from the integrated analysis of data on the hydraulic gradients of second order drainage together with data from lineament analysis. The main lineament systems are the Paratizinho, Santo Antônio, Paxamba and Cachoeira Grande Systems, which are interpreted as tectonic boundaries between blocks with neotectonic activity, specially well marked along the course of the Xingu river.

A model is proposed for the evolution of the Xingu river which shows the importance of neotectonic movements on the change in the direction of the river flow, resulting in the large are in the river, the "Volta Grande", between the cities of Altamira and Belo Monte.

The available data suggest that the study area has been in gradual uplift during the Late Cenozoic. The lineaments with directions N8OW and N30-40W, typical of the area restricted to the Xingu river course, suggest a NW direction of compression and NE direction of extension. The NWtrending structures observed in areas with abrupt lateral variations of thickness of the Quaternary sediments are indicative of reactivation of these discontinuities as normal faults.

The neotectonic stress field of the study area can be explained by the interplay between migration of the Nazca, Cocos, Caribe and South American plates and sea-floor spreading along the Mid-Atlantic Ridge, and/or, alternatively, to the isostatic response to the accumulation of the Cenozoic sediments at the mouth of the Amazon river and in the Acre and Solimōes basins, with consequent erosion in the area located between the Purus and Gurupá arches.

\section{SAYEG, Heitor Siqueira}

A evolução geológica brasileira da regiäo do Arroio Boici, RS. 23 de abril. 125p. Orientador: Rômulo Machado.

Resumo: O Vale do Arroio Boici, situado no Municipio de Pinheiro Machado, RS, foi identificado como uma bacia limitada por falhas transcorrentes, desenvolvida durante a orogenia Serra do Herval (570-530 Ma).

Essa região apresenta ampla exposiçăo de unidades sedimentares englobadas na Formação Arroio dos Nobres (sensu Fragoso Cesar, 1991), representada por sua unidades Flysch Vale do Piquiri (inferior) e Molassa Vargas (superior). 
Os estudos efetuados enfocaram análises de proveniência, determinação de paleocorrentes, a identificaçăo dos sistemas deposicionais que ali se desenvolveram e a análise dos principais falhamentos que condicionaram a bacia.

Os resultados obtidos indicam que a região sofreu basculamentos regionais, que provocaram inversōes generalizadas de paleocorrentes, associadas ao soerguimento de blocos dos quais, na região estudada, o último a soerguer foi o bloco que contém o Terreno Serra das Encantadas.

Nas fases precoces da orogenia Serra do Herval, toda a região leste do Escudo UruguaioSul-Rio-Grandense foi ocupada por uma mar epicontinental, a Antefossa Arroio dos Nobres (Fragoso Cesar, 1991), cujo registro sedimentar constitue o Flysch Vale do Piquiri. A sedimentação representativa desta etapa foi promovida por sistemas de leques subaquosos evoluindo para leques costeiros, gerados num contexto de relevo progressivamente mais desenvolvido.

Durante as etapas tardias dessa orogenia ocorreu a instalação de uma cadeia de montanhas a leste. Em conseqüência, na região anteriormente ocupada pela antefossa, instalaram-se diversas estreitas e alongadas bacias, limitadas por falhas transcorrentes sinistrais de direçăo NE. A Bacia do Arroio Boici, localizada numa zona limitrofe entre diferentes blocos crustais, é uma dessas bacias, sítios deposicionais dos depósitos tardiorogénicos reunidos na unidade superior da Formaçăo Arroio dos Nobres, a Molassa Vargas.

Os sedimentos dessa etapa foram gerados em ambientes inicialmente costeiros, passando a continentais. As análises de paleocorrentes e de proveniência indicam o isolamento tardio da regiâo, provocado pelo soerguimento e exposiçäo do Terreno Serra das Encantadas, a noroeste. Em consequêencia, desenvolveram-se leques deltaicos passando a aluviais em ambas as bordas da bacia então definida, alimentando um sistema longitudinal de rios entrelaçados, com sentido de transporte para sudoeste.

As análises dos principais falhamentos mostram que os movimentos predominantes foram sinistrais, com reativaçōes de caráter destral e sinistral associadas à abertura e expansão do Oceano Atlântico, responsáveis pela estruturação da Falha do Boici, que delimita o contato entre as unidades da Formação Arroio dos Nobres na área estudada, e pela estruturaçắo atual da regiăo.

Abstract: The Arroio Boici valley, located in the municipal area of Pinheiro Machado, RS, has been identified as a strike-slip basin formed during the Serra do Herval orogeny ( $570-530 \mathrm{Ma})$.

This region shows wide exposure of sedimentary units of the Arroio dos Nobres Formation (Fragoso Cesar, 1991) represented by the basal Vale do Piquiri Flysch and upper Vargas Molasse units.

The studies concentrated on provenance analysis, determination of paleocurrent patterns, identification of depositional systems and analysis of the main faults which controlled basin development.

The results show that the region underwent regional tilting, with widespread inversion of paleocurrent patterns, related to uplift of blocks. In the area studied, the last block uplifted was the Serra das Encantadas Terrain.

During the earliest stages of the Serra do Herval orogeny, the eastern part of the Uruguaio-Sul-Rio-Grandense Shield was occupied by an epicontinental sea in the Arroio dos Nobres foredeep (Fragoso Cesar, 1991), whose sedimentary register is the Vale do Piquiri Flysch. The typical sedimentation at this time was formed by-aqueous fan systems passing to coastal fans, and was generated by progressively raised topography.

During the later stages of the orogeny, mountain chains formed to the east. Consequently, in the area formerly occupied by the fore-deep, a number of long, narrow strike-slip basins were formed. Their limits were NE-trending, sinistral transcurrent faults. The Arroio Boici basin is one of these basins, situated at a limit between crustal blocks. Such limits were sites for the late orogenic deposition of the Vargas Molasse, the upper unit of the Arroio dos Nobres Formation. 
The sediments of this stage formed in environments which were initially coastal and evolved to continental. Paleocurrent and provenance analyses show that the region became isolated late in the evolution, the isolation caused by uplift and exposure of the Serra das Encantadas Terrain to the northwest. Deltaic fans evolved to alluvial fans at both margins of the basin which formed and fed a longitudinal braided fluvial system with southwestward transport.

Analysis of the main fault system shows that the main movements were sinistral, with both dextral and sinistral reactivations associated with the initial, opening and expansion of the Atlantic Ocean. These movements were responsible for the generation and evolution of the Boici Fault, which forms the contact between the units of the Arroio dos Nobres Formation in the studied area, and is responsible for the present structure of the region. 